\title{
Use of a Protein Engineering Strategy to Overcome Limitations in the Production of 'Difficult to Express' Recombinant Proteins
}

DOI:

10.1002/bit.26358

\section{Document Version}

Accepted author manuscript

Link to publication record in Manchester Research Explorer

Citation for published version (APA):

Hussain, H., Fisher, D., Abbott, W. M., Roth, R. G., \& Dickson, A. (2017). Use of a Protein Engineering Strategy to Overcome Limitations in the Production of 'Difficult to Express' Recombinant Proteins. Biotechnology and Bioengineering, 14(10), 2348-2359. https://doi.org/10.1002/bit.26358

\section{Published in:}

Biotechnology and Bioengineering

\section{Citing this paper}

Please note that where the full-text provided on Manchester Research Explorer is the Author Accepted Manuscript or Proof version this may differ from the final Published version. If citing, it is advised that you check and use the publisher's definitive version.

\section{General rights}

Copyright and moral rights for the publications made accessible in the Research Explorer are retained by the authors and/or other copyright owners and it is a condition of accessing publications that users recognise and abide by the legal requirements associated with these rights.

\section{Takedown policy}

If you believe that this document breaches copyright please refer to the University of Manchester's Takedown Procedures [http://man.ac.uk/04Y6Bo] or contact uml.scholarlycommunications@manchester.ac.uk providing relevant details, so we can investigate your claim.

\section{OPEN ACCESS}




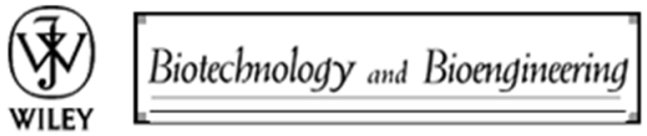

\section{Use of a Protein Engineering Strategy to Overcome Limitations in the Production of 'Difficult to Express' Recombinant Proteins}

\begin{tabular}{|r|l|}
\hline Journal: & Biotechnology and Bioengineering \\
\hline Manuscript ID & $17-126$. R1 \\
\hline Wiley - Manuscript type: & Article \\
\hline Date Submitted by the Author: & $09-$ May-2017 \\
\hline Complete List of Authors: & $\begin{array}{l}\text { Hussain, Hirra; University of Manchester, Manchester Institute of } \\
\text { Biotechnology, Faculty of Science and Engineering } \\
\text { Fisher, David; AstraZeneca, Innovative Medicines } \\
\text { Abbott, W; AstraZeneca, Innovative Medicines; Peak Proteins, BioHub } \\
\text { Roth, Robert; Astrazeneca, Innovative Medicines } \\
\text { Dickson, Alan; University of Manchester, Manchester Institute of } \\
\text { Biotechnology, Faculty of Science and Engineering }\end{array}$ \\
\hline Key Words: & $\begin{array}{l}\text { Recombinant protein production, difficult to express, mammalian } \\
\text { expression system, tissue inhibitor of metalloproteinase, secretory } \\
\text { pathway, protein engineering }\end{array}$ \\
\hline \multicolumn{2}{|c}{} \\
\hline
\end{tabular}

\section{SCHOLARONE ${ }^{m}$}

Manuscripts 
In this study, the authors present a systematic screen to characterise the mechanisms that discriminate between secretion of recombinant proteins with extensive sequence homology. A protein engineering approach was employed enhanced the production of 'difficult to express' proteins from the tissue inhibitor of metalloproteinase (TIMP) family. The addition of a furin-cleavable pro-sequence resulted in successful secretion of non-secreted (TIMP-3) and poorly secreted (TIMP-4) targets and presents a novel strategy to increase the production of 'difficult' recombinant targets.

$50 \times 38 \mathrm{~mm}(300 \times 300$ DPI $)$ 
Running title: 'Difficult to Express' Recombinant Proteins

\title{
Use of a Protein Engineering Strategy to Overcome Limitations in the Production of 'Difficult to Express' Recombinant Proteins
}

\author{
Hirra Hussain ${ }^{1}$, David I Fisher ${ }^{2}$, W Mark Abbott ${ }^{2^{*}}$, Robert G Roth ${ }^{3}$ and Alan J Dickson ${ }^{1}$ \\ ${ }^{1}$ Manchester Institute of Biotechnology, Faculty of Science and Engineering, University of Manchester, M1 7DN, \\ United Kingdom \\ ${ }^{2}$ AstraZeneca, Cambridge Science Park, Milton, Cambridge, CB4 OWG, United Kingdom \\ ${ }^{3}$ AstraZeneca, Pepparedsleden 1, Mölndal, Sweden, SE-431 83 \\ *Now at Peak Proteins, BioHub, Alderley Edge, Cheshire, SK10 4TG, United Kingdom \\ e-mail: hirra.hussain@manchester.ac.uk
}




\begin{abstract}
Certain recombinant proteins are deemed "difficult to express" in mammalian expression systems requiring significant cell and/or process engineering to abrogate expression bottlenecks. With increasing demand for the production of recombinant proteins in mammalian cells, low protein yields can have significant consequences for industrial processes. To investigate the molecular mechanisms that restrict expression of recombinant proteins, naturally secreted model proteins were analysed from the tissue inhibitors of metalloproteinase (TIMP) protein family. In particular, TIMP-2 and TIMP-3 were subjected to detailed study. TIMP proteins share significant sequence homology ( $50 \%$ identity and $\sim 70 \%$ similarity in amino acid sequence). However, they show marked differences in secretion in mammalian expression systems despite this extensive sequence homology. Using these two proteins as models, this study characterised the molecular mechanisms responsible for poor recombinant protein production. Our results reveal that both TIMP-2 and TIMP-3 are detectable at mRNA and protein level within the cell but only TIMP-2 is secreted effectively into the extracellular medium. Analysis of protein localisation and the nature of intracellular protein suggest TIMP-3 is severely limited in its post-translational processing. To overcome this challenge, modification of the TIMP-3 sequence to include a furin protease-cleavable pro-sequence resulted in secretion of the modified TIMP-3 protein, however, incomplete processing was observed. Based on the TIMP-3 data, the protein engineering approach was optimised and successfully applied in combination with cell engineering, the overexpression of furin, to another member of the TIMP protein family (the poorly expressed TIMP-4). Use of the described protein engineering strategy resulted in successful secretion of poorly (TIMP-4) and non-secreted (TIMP-3) targets, and presents a novel strategy to enhance the production of 'difficult' recombinant targets.
\end{abstract}

Keywords: Recombinant protein production, difficult to express, mammalian expression system, tissue inhibitor of metalloproteinase, secretory pathway, protein engineering. 
Introduction

For the production of recombinant proteins (for either research or drug discovery pipelines) the use of mammalian expression systems has increased significantly. Mammalian expression systems have specific advantages over other expression systems in that they can perform the post-translational modifications required for appropriate function of mammalian proteins. Chinese Hamster Ovary (CHO) cells are currently widely used for the production of recombinant proteins (Walsh, 2014). Of the total biopharmaceuticals approved between $2010-2014,33 \%$ (54 products) were produced in CHO expression systems (Walsh, 2014). To address this rising need, transient mammalian expression systems have been developed that allow rapid generation of high recombinant protein titres for research purposes (Cain et al., 2013, Daramola et al., 2014).

Large scale production of recombinant proteins in mammalian cells can be influenced by many potentially limiting steps or 'bottlenecks' along the protein expression pathway (Hussain et al., 2014). Many mammalian cell-derived recombinant proteins are produced as secreted targets, a feature associated with the natural pathway of post-translational processing. The balance between the different processes, associated factors and protein quality control mechanisms all affect the rate at which proteins transit through the protein expression pathway and are secreted from the cell (Hussain et al., 2014). Due to the complexity of mammalian expression systems, limitations may give rise to unpredictability in the production of certain recombinant proteins. So called 'difficult-to-express' recombinant proteins lead to lack of process robustness and inability to generate sufficient quantities.

Several examples have been published of limitations in recombinant protein production, mainly of monoclonal antibodies (mAbs) (Barnes et al., 2004, Johari et al., 2015, Mason et al., 2012, Pybus et al., 2014b, Stoops et al., 2012). Other studies have identified that certain molecular features within mAb sequences may be responsible for differences in production (Pybus et al., 2014b). In addition, certain sequences are predisposed to form intracellular aggregates (e.g. Russell bodies) under certain host cell conditions (Stoops et al., 2012). As a result, a range of different engineering strategies has been employed to overcome these 'bottlenecks' and increase protein production.

Attempts to improve the overall capacity of cells to express greater amounts of secreted recombinant proteins have involved host cell engineering targeted at endoplasmic reticulum (ER) chaperones 
(Chung et al., 2004, Dorner et al., 1989, Johari et al., 2015), protein disulphide isomerases (Borth et al., 2005, Mohan and Lee, 2010) as well as unfolded protein response mediators (Becker et al., 2010, Cain et al., 2013, Haredy et al., 2013, Ku et al., 2008, Ku et al., 2010, Omasa et al., 2008, Tigges and Fussenegger, 2006). Other sites of engineering have included overexpression of machinery related to the import of nascent polypeptide chains into the ER (Le Fourn et al., 2014) and vesicular transport components (Peng and Fussenegger, 2009, Peng et al., 2010, Peng et al., 2011). Alternative approaches have sought to enhance secretory capacity by increasing the ratio of light chain to heavy chain genes for mAb production (Pybus et al., 2014a, Pybus et al., 2014b), use of hypothermic conditions (Ahn et al., 2008, Jenkins and Hovey, 1993, Kantardjieff et al., 2010, Kaufmann et al., 1999) or the addition of chemical chaperones to cell cultures (Johari et al., 2015, Roth et al., 2012).

Synthetic signal peptides and leader sequences have been used extensively in yeast expression systems to enhance heterogeneous protein production (Brake et al., 1984, Heiss et al., 2015, Hou et al., 2012, Rakestraw et al., 2009). Use of the yeast mutant alpha mating factor 1 leader peptide (MFa1pp) in mammalian cells (rat pituitary-derived cell line) resulted in efficient ER-Golgi translocation of a neuropeptide (somatostatin), but led to inefficient processing and intracellular accumulation during later stages of the secretory pathway (Lee et al., 2002).

Although different studies have shown some degree of overlap in terms of localisation of the limiting steps identified, it is difficult to compare studies and their interpretations directly as each involves the expression of different proteins within distinct mammalian cell lines. Engineering strategies employed may have a protein-specific effect and pursuance of protein-specific host cell engineering would be very laborious for large-scale production of extended panels of recombinant proteins. Fundamental understanding of the molecular mechanisms that restrict recombinant protein production would offer universal strategies to overcome this challenge.

In this study, members of the tissue inhibitor of metalloproteinase (TIMP) protein family, specifically TIMP-2 and TIMP-3, were selected as model proteins to define molecular determinants of the extent of recombinant protein production. TIMPs are highly disulphide-bonded, low molecular weight proteins that share significant sequence $(\sim 50 \%$ identity and $\sim 70 \%$ similarity in amino acid sequence) and structural homology (Brew et al., 2000, Douglas et al., 1997, Melendez-Zajgla et al., 2008). However, 
past studies in mammalian expression systems have shown that these TIMPs exhibit large differences in their production (unpublished data). Here we define a step-by-step screen to define the limiting steps in the protein expression pathway in a transient $\mathrm{CHO}$ expression system. From this approach, we have developed a protein engineering strategy that enables production of the very poorly expressed TIMP-3, and successfully applied to another 'difficult-to-express' target and member of the TIMP protein family (poorly secreted TIMP-4). Together the data suggested the application of such a protein engineering approach, may have generic implications towards the enhanced production of 'difficult-to-express' recombinant proteins.

\section{Materials and Methods}

\section{Constructs}

All gene inserts were synthesised, codon-optimised for $\mathrm{CHO}$ expression and cloned into pDEST12.2OriP (Abbott et al., 2015). Rat tissue inhibitor of metalloproteinase-2 (TIMP-2, 654bp), TIMP-3 (636bp) and TIMP-4 (660bp) all carry a CD33 signal peptide and C-terminal 6xHis tag (Figure 1). Further, a separate set of constructs were synthesised where TIMP-3 and TIMP-4 sequences were modified to include a 103 amino acid, furin-cleavable (fc) pro-sequence, generating fcTIMP-3 and fcTIMP-4 respectively. In addition, the fcTIMP-4 construct contained a short linker (Glycine-Serine, GS) between the pro-sequence and the TIMP-4 sequence. The furin-cleavable pro-sequence was taken from nerve growth factor of mouse origin (amino acid sequence: EPYTDSNVPEGDSVPEAHWTKLQHSLDTALRRARSAPTAPIAARVTGQTRNITVDPRLFKKRRLHSP RVLFSTQPPPTSSDTLDLDFQAHGTIPFNRTHRSKR) (Selby et al., 1987, Suter et al., 1991, Seidah et al., 1996). Human furin was cloned into pDEST12.2-OriP for co-expression analyses. All DNA solutions were prepared under sterile conditions at $1 \mathrm{mg} / \mathrm{ml}$ in TE buffer $(10 \mathrm{mM}$ Tris, $\mathrm{pH}$ 8.0, $1 \mathrm{mM}$ EDTA).

Transient expression in mammalian expression systems

HEK293-6E cells (National Research Council, Biotechnological Research Institute, Montreal, Canada) were routinely passaged and maintained between $0.2-2.5 \times 10^{6}$ cells $/ \mathrm{ml}$ in $\mathrm{F} 17$ medium (Life

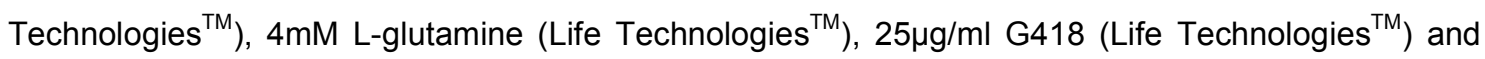
$0.1 \%(\mathrm{v} / \mathrm{v})$ Pluronic F68 ${ }^{\mathrm{TM}}$ (Life Technologies ${ }^{\mathrm{TM}}$ ) (Raymond et al., 2011). For transient expression, 
cells were seeded at $8 \times 10^{5}$ cells $/ \mathrm{ml}$ in F17 medium $24 \mathrm{~h}$ prior to transfection. Cultures were incubated at $37^{\circ} \mathrm{C}, 5 \% \mathrm{CO}_{2}, 140 \mathrm{rpm}$ in an orbital incubator $(25 \mathrm{~mm}$ orbit). Cells were counted and transfected at 1.6-1.8 $\times 10^{6} \mathrm{cells} / \mathrm{ml}$ with $0.75 \mu \mathrm{g} / \mathrm{ml}$ DNA and $2.8 \mu \mathrm{g} / \mathrm{ml}$ 40,000kDa PEI Max (Polysciences). $24 \mathrm{~h}$ posttransfection the cultures were fed with 0.3\% (v/v) HyPep 1510 (Kerry Bioscience) prepared in F17 medium. Cell density and viability were monitored daily. Aliquots of culture medium were removed at the end of the culture period and harvested/clarified by centrifugation $\left(2500 \times \mathrm{g}, 15 \mathrm{~min}, 4^{\circ} \mathrm{C}\right)$. Culture supernatants were isolated and stored at $-80^{\circ} \mathrm{C}$.

Transient expression in Chinese Hamster Ovary (CHO) cells

CHO-EBNA-GS cells (Daramola et al., 2014) were routinely passaged as described by Abbott et al., (2015). Protein expression of DNA constructs was adapted from the methodology described by Abbott et al., (2015). CHO-EBNA-GS cells were seeded at $5 \times 10^{5}$ cells $/ \mathrm{ml}$ in $\mathrm{CD} \mathrm{CHO}$ medium (Life Technologies $^{\mathrm{TM}}$ ) $24 \mathrm{~h}$ prior to transfection. Cultures were incubated at $37^{\circ} \mathrm{C}, 5 \% \mathrm{CO}_{2}, 140 \mathrm{rpm}$ in an orbital incubator $\left(25 \mathrm{~mm}\right.$ oribit). Cells were transfected at $1-1.2 \times 10^{6}$ cells $/ \mathrm{ml}$ with $0.5 \mu \mathrm{g} / \mathrm{ml}$ DNA and $7 \mu \mathrm{g} / \mathrm{ml}$ 40,000kDa PEI Max (Polysciences). $24 \mathrm{~h}$ post-transfection the cultures were fed with $0.5 \%$ (v/v) Tryptone N1 (Organotechnie) in CD CHO medium. For hypothermic growth assessment, on day 3 post-transfection, CHO-EBNA-GS cultures were incubated at $30^{\circ} \mathrm{C}, 5 \% \mathrm{CO}_{2}, 140 \mathrm{rpm}$ in an orbital incubator (25mm orbit).

The cell density and viability were monitored daily for transfected cultures. At specific time points, samples were removed and harvested/clarified by centrifugation $\left(10,000 \times \mathrm{g}, 30 \mathrm{mins}, 4^{\circ} \mathrm{C}\right)$. Cell pellets and culture supernatant were isolated and stored at $-80^{\circ} \mathrm{C}$.

Hypothermic growth conditions

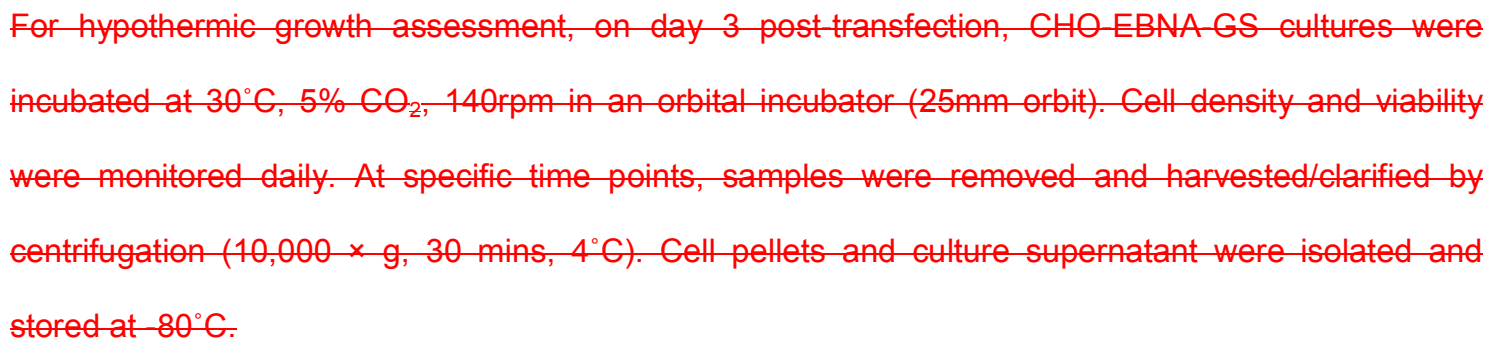


'Difficult to Express' Recombinant Proteins

\section{Protein purification}

Proteins were purified using the $6 \times$ His tag from culture supernatant samples using a PhyNexus MEA workstation as described by Abbott et al., (2015). Non-purified (crude) and purified samples were analysed using non-reducing SDS-PAGE.

\section{Messenger RNA (mRNA) analysis}

All solutions for analysis of mRNA were prepared in RNase- and DNase-free water. CHO-EBNA-GS cells $\left(1 \times 10^{7}\right.$ cells $)$ were harvested by centrifugation $(500 \times \mathrm{g}, 10$ mins $)$ on days 3,5 and 6 posttransfection for RNA isolation. The cell pellet was lysed in $1 \mathrm{ml}$ Trizol $^{\circledR}$ reagent and processed according to the manufacturer's instructions. The nucleic acid concentration and purity was determined using a Nanodrop ${ }^{\circledR}$ ND-1000 UV-Vis spectrophotometer. Genomic DNA was removed with DNase 1 (New England Biolabs ${ }^{\circledR}$ Inc.) digestion. The resulting RNA was converted to complementary DNA (cDNA) in a total reaction volume of $60 \mu l$ using Tetro cDNA synthesis kit (Bioline) as per the manufacturer's instructions using a TC-3000 Thermal Cycler (Techne). Subsequent cDNA was analysed by both reverse transcription polymerase chain reaction (RTPCR) and quantitative real-time PCR (qRT-PCR). Primers for both RT-PCR and qRT-PCR were designed using Serial Cloner and synthesised by Eurofins Genomics (Table I).

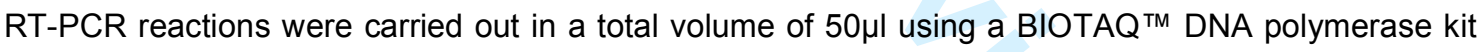
(Bioline) as per the manufacturer's instructions with $1 \mathrm{pmol}$ of each primer and $1 \mu \mathrm{l}$ cDNA. The TC $3000 \times$ thermal cycler programme was as follows; $94^{\circ} \mathrm{C} 5$ mins, then 27 cycles of $94^{\circ} \mathrm{C} 30$ secs, annealing temperature at ( $\mathrm{Ta}$, Table I) for 30 secs, $72^{\circ} \mathrm{C} 30$ secs then $72^{\circ} \mathrm{C}$ for 10 mins. The $\beta-2-$ microglobulin (B2M) housekeeping gene was used as a positive control. PCR products were resolved on a $2 \%(w / v)$ or $3 \%(w / v)$ agarose gel.

cDNA was quantified using the SensiFast ${ }^{\mathrm{TM}}$ SYBR® probe Hi-ROX kit (Bioline) with $5 \mu$ l diluted cDNA (1:10) or water (non-template control) using the StepOnePlus ${ }^{\mathrm{TM}}$ Real-Time PCR system. The following qRT-PCR programme was run, $95^{\circ} \mathrm{C} 2$ mins, then 40 cycles of $95^{\circ} \mathrm{C} 5$ secs, Ta (Table I) for 10 secs and $72^{\circ} \mathrm{C} 20$ secs. A melting curve was generated to check the quality of the PCR products. The cycle number at which samples reached the threshold (Ct value) was determined. A 5-point 
standard curve was generated for each cDNA sample. Log cDNA concentration was plotted against the $\mathrm{Ct}$ value. Samples for analysis were diluted within the linear range of the standard curve $(1: 10)$. Ct values were normalised to the housekeeping gene (B2M) to give a $\mathrm{Ct}$ ratio. The $\mathrm{Ct}$ ratio was used for comparison between different samples.

\section{Intracellular and secreted protein analysis}

For protein analyses $5 \times 10^{6}$ cells were harvested by centrifugation $(500 \times \mathrm{g}, 10 \mathrm{mins})$ and the culture supernatant was collected. The cell pellet was lysed directly in $2 \times$ sample buffer $(20 \%(\mathrm{v} / \mathrm{v})$ glycerol, $125 \mathrm{mM}$ Tris- $\mathrm{HCl}, 4 \%(\mathrm{w} / \mathrm{v})$ SDS, $0.01 \%(\mathrm{v} / \mathrm{v})$ bromophenol blue) with dispersion through a syringe and 21 gauge needle to assess intracellular protein. For secreted protein the culture supernatant was mixed in equal volumes with $2 \times$ sample buffer prior to western blot analysis. Both intracellular and secreted protein samples were resolved on $12.5 \%$ (w/v) SDS-PAGE gels using the Bio-Rad mini PROTEAN Tetra system under non-reducing or reducing (with $1.8 \%$ (v/v) $\beta$-mercaptoethanol) conditions. Proteins separated by SDS-PAGE were transferred onto a nitrocellulose membrane using the Bio-Rad Semi-Dry transfer system according to the manufacturer's instructions. Membranes were blocked in $5 \%(\mathrm{w} / \mathrm{v})$ milk in phosphate buffered saline (PBS, $137 \mathrm{mM} \mathrm{NaCl}, 2.7 \mathrm{mM} \mathrm{KCl}, 10 \mathrm{mM}$ $\mathrm{Na}_{2} \mathrm{HPO}_{4}, 2 \mathrm{mM} \mathrm{KH}_{2} \mathrm{PO}_{4}, \mathrm{pH} 7.4$ ) with $0.1 \%(\mathrm{v} / \mathrm{v})$ Tween-20 for $1 \mathrm{~h}$ at room temperature before being incubated for $1 \mathrm{~h}$ with primary antibodies. The following primary antibodies were used, anti- $6 \times \mathrm{His}$ tag (1:2000, cat no. ab18184, Abcam), ERK2 (1:1000, cat no. sc-81459, Santa Cruz Biotechnology), BiP/GRP78 (1:1000, cat no. sc-1050, Santa Cruz Biotechnology), Histone H3 (1:1000, cat no. 9717, New England Biolabs ${ }^{\circledR}$ Inc.) and Flotillin-2 (1:1000, cat no. 3436, New England Biolabs ${ }^{\circledR}$ Inc.). Membranes were then incubated with the appropriate IRDye ${ }^{\circledR} 800 \mathrm{CW}$ secondary antibody (1:15000, LI-COR Biosciences). Proteins were detected using infrared fluorescent imaging LI-COR Odyssey ${ }^{\circledR}$ Classic imager according to the manufacturer's instructions. Quantification of bands was completed using the LI-COR Image Studio ${ }^{\mathrm{TM}}$ Lite software. All graphs were plotted in Graphpad Prism ${ }^{\circledR}($ Version 6.02). Statistical analysis was also performed in Graphpad.

\section{Cellular compartment fractionation}

CHO-EBNA-GS cells $\left(1 \times 10^{7}\right)$ were taken from transiently transfected cultures on day 5 after transfection. Cells were pelleted by centrifugation $(500 \times \mathrm{g}, 10 \mathrm{mins})$. Cell pellets were fractionated 
'Difficult to Express' Recombinant Proteins

using a Qproteome ${ }^{\circledR}$ cell compartment kit (QIAGEN) as per the manufacturer's instructions. An aliquot of each isolated fraction was mixed in equal volumes with $2 \times$ sample buffer for western blot analysis.

\section{Glycosidase treatment}

CHO-EBNA-GS cells $\left(5 \times 10^{6}\right)$ were taken from transiently transfected cultures on day 5 . Cells were harvested by centrifugation $(500 \times \mathrm{g}, 10 \mathrm{mins})$ and lysed in RIPA buffer $(125 \mathrm{mM}$ sodium chloride, $10 \mathrm{mM}$ sodium fluoride, $1 \%(\mathrm{v} / \mathrm{v})$ Triton-X, $0.2 \%(\mathrm{w} / \mathrm{v})$ SDS, $10 \mathrm{mM}$ sodium pyrophosphate, $0.5 \%(\mathrm{w} / \mathrm{v})$ sodium deoxycholate, $25 \mathrm{mM}$ HEPES and $10 \mathrm{mM}$ sodium orthovanadate) using a syringe and 21 gauge needle. For each glycosidase treatment, three samples $(30 \mu \mathrm{l}$ each) of the lysate were isolated. An untreated sample was mixed directly in equal volumes with $2 \times$ sample buffer. For N-Glycosidase $\mathrm{F}$ (Roche) treatment, $1.8 \mu \mathrm{l}$ of $\mathrm{N}$-Glycosidase $\mathrm{F}$ enzyme (1 unit/ $\mu \mathrm{l}$ ) was added per $30 \mu \mathrm{l}$ lysate and incubated overnight at $37^{\circ} \mathrm{C}$. Alternatively, samples for Endoglycosidase $\mathrm{H}$ (New England Biolabs ${ }^{\circledR}$ ) treatment were processed according to the manufacturer's instructions. Glycoproteins were denatured by combining $2.5 \mu \mathrm{l}$ of glycoprotein denaturing buffer $(10 \times)$ with $22.5 \mu$ l lysate and incubated for 10 mins at $100^{\circ} \mathrm{C}$. $3 \mu \mathrm{l}$ of $\mathrm{G} 5$ reaction buffer $(10 \times), 1 \mu \mathrm{l}$ Endoglycosidase $\mathrm{H}(500$ units/ $\mu \mathrm{l})$ and water were added to make a total reaction volume of $30 \mu \mathrm{l}$. The reaction was incubated for $1 \mathrm{~h}$ at $37^{\circ} \mathrm{C}$. Samples were subsequently mixed with $2 \times$ sample buffer and analysed by western blot.

\section{Results and Discussion}

\section{Preliminary characterisation identifies differences in recombinant TIMP protein production}

The CHO-EBNA-GS cell line has previously been shown to offer a rapid and high yielding transient expression system (Abbott et al., 2015, Daramola et al., 2014). We have used this expression system to understand the molecular mechanisms responsible for specific poor recombinant protein production. Initially, two TIMP proteins that had previously been shown to display two extremes in their production (TIMP-2 and TIMP-3) were subject to detailed analysis in the CHO-EBNA-GS cell line. TIMP-2 was secreted well, whereas TIMP-3 was undetectable in the extracellular medium (Figure S1a). When placed under hypothermic growth conditions $\left(30^{\circ} \mathrm{C}\right)$, a situation known to enhance production of specific proteins (Ahn et al., 2008, Kantardjieff et al., 2010), TIMP-2 was 
secreted in greater amounts than at $37^{\circ} \mathrm{C}$, whereas TIMP-3 was undetectable in the medium at either culture temperature. TIMP-3 was undetectable in either crude or purified culture medium samples. For both proteins, higher molecular weight species were detectable in the medium, possibly host cell proteins co-purifying during protein purification. An additional higher molecular weight species ( $42 \mathrm{kDa})$ was observed in TIMP-2 transfected samples, predicted to be a dimeric form of TIMP-2. Other studies have also reported the presence of TIMP-2 in a dimeric form (Berthier et al., 2006, Zucker et al., 1998). An increase in cell productivity in response to hypothermia has been attributed to several processes, such as an increase in secretory pathway components (Kantardjieff et al., 2010). This increase in cell productivity was reflected by the increase in secreted TIMP-2 protein observed under hypothermic conditions. However, as TIMP-3 was not detectable in the medium we proposed the limitation in TIMP-3 production was independent of the cellular processes affected by shifting to a lower temperature.

The difference in production of TIMP-2 and TIMP-3 observed in the CHO expression system, was also observed with the HEK293-6E cell line (Figure S1b). TIMP-2 was detectable in the culture medium mainly in its monomeric form, with the presence of an additional higher molecular weight species. Therefore, we concluded this difference in production between both TIMP proteins was independent of the host cell type.

\section{Differences in TIMP protein production are not due to effects on cell growth}

To examine the consequence of recombinant protein "load" on cell growth, both TIMP-2 and TIMP-3 were transiently transfected in the CHO-EBNA-GS cell line. Cells transfected with enhanced GFP (eGFP) were used as a control to compare cell growth. For all vectors, transfection resulted in growth arrest and a drop in cell viability $24 \mathrm{~h}$ post-transfection (Figure 2). It is known that PEI can be cytotoxic to cells (Boeckle et al., 2004) and a similar initial drop in viability has been reported for other PEIbased transfections (Backliwal et al., 2008, Codamo et al., 2011, Mozley et al., 2014, Xie et al., 2013). Upon the addition of feed (Tryptone N1) $24 \mathrm{~h}$ post-transfection, the cells began to grow and viability recovered, an effect in keeping with reports of others on cell growth and recombinant protein production (Pham et al., 2005). A similar cell growth profile was observed for control (eGFP), TIMP-2 
and TIMP-3. Overall, differences in productivity of different recombinant proteins were not a result of altered cell growth or viability.

\section{mRNA amount does not limit TIMP-3 protein production}

Following preliminary characterisation of protein production, we examined processes at specific points along the protein expression pathway. Semi-quantitative RT-PCR analysis of TIMP-2 and TIMP-3 showed that mRNA was present for both proteins throughout the culture period (Figure 3a) and this observation was confirmed by quantitative RT-PCR analysis (Figure 3b). Little difference was seen between the amount of mRNA for TIMP-2 and TIMP-3. The results suggested that the amount of mRNA was not a limiting factor for the expression of TIMP-3 and the rate-limiting step lay downstream of transcription.

\section{Intracellular protein localisation studies reveals that post-translational processing of TIMP-3 may be limiting}

Next the presence and nature of intracellular and secreted protein was evaluated. For greater sensitivity in detection, proteins were detected using a specific $6 \times$ His tag antibody for western blot analysis (Figure 4). Under reducing conditions of gel electrophoresis, TIMP-2 ( 21kDa) was secreted in increasing amounts during progression of culture whereas a relatively constant amount (per cell) of intracellular TIMP-2 monomer was present throughout the culture period (Figure 4a). In addition, intracellular samples showed a $42 \mathrm{kDa}$ species (predicted to be a TIMP-2 dimer) plus an additional higher molecular weight species $(\sim 58 \mathrm{kDa})$. The $\sim 58 \mathrm{kDa}$ species was also detectable in intracellular extracts from non-transfected controls, suggesting this was an immunological cross-reaction of a nonspecific intracellular host cell protein.

Under non-reducing conditions of gel electrophoresis, multiple forms of secreted TIMP-2 were detected (Figure S2a), TIMP-2 monomer $(\sim 21 \mathrm{kDa})$, and predicted multimeric forms of TIMP-2 $(\sim 42 \mathrm{kDa}$ and $\sim 60 \mathrm{kDa})$. These results were consistent with data from the preliminary characterisation of secreted protein using non-reducing SDS-PAGE (Figure S1). 
In comparison, TIMP-3 was not detectable in medium samples but could be detected in intracellular samples, where immunoblotting identifies two species $(\sim 21 \mathrm{kDa}$, the expected non-glycosylated form and $\sim 23 \mathrm{kDa}$, the expected glycosylated form) (Figure 4b) (Apte et al., 1995). As observed with TIMP2 , an intracellular high molecular weight species at $\sim 42 \mathrm{kDa}$ was detected upon immunoblotting. Similarly, under non-reducing gel electrophoresis conditions this higher molecular weight species was consistently observed (Figure S2b). This high molecular weight species could correspond to highly stable TIMP dimers, or cross-linkage to an unknown protein of similar size.

As both TIMPs were expressed intracellularly but only TIMP-2 was secreted, the intracellular protein localisation was analysed. Protein localisation of TIMP-transfected cells was analysed via cellular fractionation with immunoblotting.

Cellular fractionation of TIMP-transfected cells separated the cell into four distinct fractions, cytosol, membranes (organellar), nuclear and cytoskeleton. Non-transfected cells were used as a negative control. Samples were taken for western blot analysis using an anti-6xHis antibody (Figure 5). The efficiency of fractionation was determined using fraction-specific marker proteins (Figure S3). A good separation between the fractions was observed with little cross-contamination. TIMP-2 and TIMP-3 proteins exhibited a similar profile, being localised to the membrane/organellar and the cytoskeleton fractions (Figure 5b, c). TIMP-3 localised to these fractions was detected mainly as the higher molecular weight glycosylated form (Figure 5c). The presence of TIMP-3 in its glycosylated form indicated that this protein species had undergone some degree of post-translational processing, suggesting that TIMP-3 secretion was limited at specific, but not the earliest, steps in organelle transportation within the protein expression pathway.

\section{Glycosidase treatment of Intracellular TIMP-3 shows the presence of immature N- glycan sugars}

As TIMP-3 has the potential to undergo N-linked glycosylation modification and TIMP-2 does not, the nature of sugar chains on TIMP-3 was profiled by glycosidase treatment. PNGase F enzymatically cleaves the bond between the polypeptide backbone (asparagine amino acid) and the first GlcNAc sugar in N-glycosylated proteins (Figure 6a) (Maley et al., 1989). In comparison, Endo H cleaves between the first two GICNAc sugars (Figure 6a) if the glycan contains a high mannose or hybrid (no 
more than two or three types of sugar) structure (Maley et al., 1989, Tarentino et al., 1989). Fullyprocessed complex glycans, after modification in the Golgi, are resistant to cleavage by Endo $\mathrm{H}$ (Medzihradszky, 2005). Therefore, Endo $\mathrm{H}$ cleavage can be indicative of the presence of immature glycoproteins that reside within the ER and have not reached the Golgi for further processing (Medzihradszky, 2005). Intracellular TIMP-3 was sensitive to both PNGase F and Endo H (Figure 6b). These data suggest the presence of high mannose/hybrid sugars on TIMP-3 that have not undergone the full extent of processing in the Golgi. Potentially, the intracellular material for TIMP-3 may be targeted for degradation.

To test whether this ER retention was due to a limitation in specific glycosylation steps, a glycan knockout of TIMP-3 (asparagine at position 184 to alanine mutation) was generated and the intracellular and secreted protein were characterised by western blot (Figure 6c). Knocking out the single glycan site on TIMP-3 did not result in successful production of TIMP-3 in the extracellular medium. This observation was confirmed with western blot analyses using a primary antibody specific for TIMP-3 (data not shown). As a result, the limitation could be refined to either aberrant TIMP-3 folding causing ER retention or a block in ER to Golgi vesicular transport.

\section{Protein engineering of TIMP-3 to overcome the block in post-translational processing results in the secretion of a modified TIMP-3 species}

To overcome the predicted post-translational limitation, the TIMP-3 vector was modified to create a fusion protein that included a short pro-sequence from a secretory growth factor (Selby et al., 1987, Suter et al., 1991, Seidah et al., 1996) that contains native cleavage sites for the protease furin (Figure 7a). Many proteins targeted for secretion contain pro-sequences that undergo proteolytic cleavage by proteases such as furin to create mature proteins (Schafer et al., 1995, Shapiro et al., 1997). As furin localises mainly to the trans-Golgi network (Schafer et al., 1995, Takahashi et al., 1995), we hypothesised that the attachment of a furin-cleavable pro-sequence would 'pull' the protein through the protein expression pathway to the trans-Golgi. Alternatively, the pro-sequence may act to promote correct protein folding or mask unfavourable sequence/structural attributes resulting in efficient processing. Consequently, this would offer the potential to overcome a limitation in transition 
from the ER to Golgi to allow its subsequent processing and sorting to the plasma membrane for secretion.

The presence of intracellular and secreted protein in furin-cleavable TIMP-3 (fcTIMP-3) in transfected CHO-EBNA-GS cultures was evaluated by western blot (Figure 7b). Immunoblotting with the 6xHis tag detection antibody, TIMP-3 was detected in the culture medium as two higher than expected molecular weight species of $\sim 40 \mathrm{kDa}$ and $\sim 50 \mathrm{kDa}$, predicted to be un-cleaved or partially cleaved fcTIMP-3 intermediates. The results showed that these species were fully processed N-glycosylated secreted forms of fcTIMP-3 due to their sensitivity to PNGase F and resistance to Endo $\mathrm{H}$ cleavage (Figure 7c). The large decrease in molecular weight following PNGase $F$ treatment confirmed the likely presence of multiple N-glycan sites. An intracellular fcTIMP-3 species was detected at $\sim 46 \mathrm{kDa}$, which was sensitive to both glycosidases suggesting it was of an immature form yet to complete processing.

Initially, the incomplete processing of fcTIMP-3 was attributed to low amounts of endogenous furin reported in CHO cells (Doolan et al., 2008, Shapiro et al., 1997). However, co-expression of furin and fcTIMP-3 (1:1 DNA ratio) failed to increase processing of fcTIMP-3 intermediates. Instead there was little intracellular protein and no secreted TIMP-3 in cell extracts and the culture medium respectively (data not shown). It has been suggested that although furin mainly localises to the trans-Golgi (Schafer et al., 1995, Shapiro et al., 1997), it has the ability to move between the trans-Golgi, ER, endosomes and cell surface, cleaving different substrates in each compartment (Bass et al., 2000, Bosshart et al., 1994, Chia et al., 2011, Han et al., 2008, Molloy et al., 1994, Schafer et al., 1995, Takahashi et al., 1995, Thomas, 2002). Therefore, the overexpression of furin may result in its colocalisation with TIMP-3 and lead to subsequent degradation. An alternative hypothesis (rather than low amounts of furin) is that the observed incomplete processing of fcTIMP-3 may result from restricted access to the furin cleavage site (site 2) within the pro-sequence, due to the adjacency of an $\mathrm{N}$-glycan site (Figure 7a). Peptide mapping by mass spectroscopy techniques could potentially confirm non- or partial cleavage of the pro-sequence. Overall, despite improper processing of fcTIMP3 , use of the furin-cleavable pro-sequence resulted in the secretion of a TIMP-3 species in the culture medium, an outcome that would make possible harvest of an otherwise un-harvestable product. 
The application of the protein engineering strategy results in the correct processing and increased secretion of a second 'difficult to express' target

The applicability of the protein engineering strategy was tested on another 'difficult to express' target. Previous characterisation of TIMP-4, another member of the TIMP protein family, showed that TIMP-4 was poorly secreted into the extracellular medium (Figure S4a, b). TIMP-4 was observed to accumulate within cells in large amounts compared to TIMP-2 and TIMP-3 (Figure S4c) and showed evidence of protein degradation (Figure S4b), which suggested it was limited in post-translational processing. The DNA construct for TIMP-4 was modified to include the furin-cleavable pro-sequence (fcTIMP-4). Further, based on the fcTIMP-3 data, the construct was modified to include a short linker (GS) between the pro-sequence and the TIMP-4 sequence to enhance accessibility to the second furin-cleavage site (site 2).

CHO-EBNA-GS cultures were transfected with fcTIMP-4 and the intracellular and secreted protein were analysed by western blot and SDS-PAGE (Figure 8 and Figure S5 respectively). In the culture medium, TIMP-4 monomer ( 25kDa) was detected in significantly increasing amounts as the culture progressed (Figure 8a, c, P value $<0.0001$ ) and comparable to the well-secreted TIMP-2 (Figure S5a). In addition, the amount of secreted fcTIMP-4 was significantly greater than that of the un-modified TIMP-4 control (culture medium sampled on day 6, P value < 0.0001) (Figure 8c and Figure S5b). Higher molecular weight species between $\sim 32 \mathrm{kDa}-50 \mathrm{kDa}$ were also detected in the medium (predicted to be incompletely cleaved intermediates of fcTIMP-4). The presence of these higher molecular weight species was diminished upon co-expression of furin with fcTIMP-4 (Figure 8b). Whilst significantly decreased amounts of TIMP-4 ( $P$ value $<0.0001)$ were detectable in the culture medium after furin co-expression (Figure 8c), this contrasted with the situation observed with fcTIMP3 , where expression of furin prevented secretion of fcTIMP-3 without the linker sequence.

Under conditions with and without furin co-expression, little monomeric fcTIMP-4 protein was detectable in cell extracts (Figure 8d). In comparison, the amount of non-modified TIMP-4 protein (sampled on day 6) was significantly higher than fcTIMP-4 in cell extracts (Figure 8e). Use of the fcTIMP-4 format resulted in successful secretion, with little protein retained in cell extracts. Potentially, addition of the linker to fcTIMP-3 may result in efficient processing as observed with fcTIMP-4. 
Synthetic signal peptides and leader sequences have been used extensively in yeast expression systems to enhance heterogeneous protein production (Brake et al., 1984, Heiss et al., 2015, Hou et al., 2012, Rakestraw et al., 2009). Use of the yeast mutant alpha mating factor 1 leader peptide (MFa1pp) in mammalian cells (rat pituitary-derived cell line) resulted in efficient ER-Golgi translocation of a neuropeptide (somatostatin), but led to inefficient processing and intracellular accumulation during later stages of the secretory pathway (Lee et al., 2002). Use of the furincleavable pro-sequence as described in this study, has not been previously reported as a strategy to increase the expression of 'difficult to express' recombinant proteins in mammalian cells.

\section{Summary and Outlook}

In this study we have described a systematic screen for the identification of limiting steps in the production of a model 'difficult 'to express' recombinant target, TIMP-3. Characterisation of both the intracellular and secreted protein suggested TIMP-3 production was severely limited in its posttranslational processing and that partly-processed species underwent retention within the ER. Published studies have explored strategies to increase recombinant protein production by altering cell culture conditions or host cell line engineering and some have addressed the limitations in the production of specific 'difficult' targets. In this study, to overcome limitations in post-translational processing, use of the furin-cleavable pro-sequence resulted in the secretion of the modified TIMP-3 protein, however, incomplete processing was observed. Further optimisation of the vector design to prevent aberrant processing resulted in the correct processing and secretion of a second 'difficult' target. Therefore, use of a cleavable pro-sequence has shown to be a viable engineering strategy with generic implications on the secretion of 'difficult' recombinant targets. Use of the furin-cleavable pro-sequence as described in this study, has not been previously reported as a strategy to increase the expression of 'difficult to express' recombinant proteins in mammalian cells. Future avenues to explore include the evaluation of the pro-sequence in the production of complex targets and in alternative mammalian expression systems. Incorporation of the pro-sequence as part of the DNA vector design, could potentially act as a novel generic method to increase processing and targeting for secretion of recombinant targets. 
'Difficult to Express' Recombinant Proteins

\section{Acknowledgments}

This research was made possible by financial support from AstraZeneca and the Biotechnology and Biological Sciences Research Council (BBSRC) via a CASE postgraduate studentship to Hirra Hussain. The authors would also like to acknowledge colleagues at the University of Manchester, AstraZeneca and Medlmmune for their advice and support.

\section{References}

ABBOtT, W. M., MIDDLETON, B., KARTBERG, F., CLAESSON, J., ROTH, R. \& FISHER, D. 2015. Optimisation of a simple method to transiently transfect a $\mathrm{CHO}$ cell line in high-throughput and at large scale. Protein Expression and Purification, 116, 113-119.

AHN, W. S., JEON, J. J., JEONG, Y. R., LEE, S. J. \& YOON, S. K. 2008. Effect of Culture Temperature on Erythropoietin Production and Glycosylation in a Perfusion Culture of Recombinant CHO Cells. Biotechnology and Bioengineering, 101, 1234-1244.

APTE, S. S., OLSEN, B. R. \& MURPHY, G. 1995. The gene structure of tissue inhibitor of metalloproteinases (TIMP)-3 and its inhibitory activities define the distinct timp gene family. Journal of Biological Chemistry, 270, 14313-14318.

BACKLIWAL, G., HILDINGER, M., HASIJA, V. \& WURM, F. M. 2008. High-density transfection with HEK-293 cells allows doubling of transient titers and removes need for a priori DNA complex formation with PEI. Biotechnology and Bioengineering, 99, 721-727.

BARNES, L. M., BENTLEY, C. M. \& DICKSON, A. J. 2004. Molecular definition of predictive indicators of stable protein expression in recombinant NSO myeloma cells. Biotechnology and Bioengineering, 85, 115-121.

BASS, J., TURCK, C., ROUARD, M. \& STEINER, D. F. 2000. Furin-mediated processing in the early secretory pathway: Sequential cleavage and degradation of misfolded insulin receptors. Proceedings of the National Academy of Sciences of the United States of America, 97, 11905-11909. 
BECKER, E., FLORIN, L., PFIZENMAIER, K. \& KAUFMANN, H. 2010. Evaluation of a combinatorial cell engineering approach to overcome apoptotic effects in XBP-1(s) expressing cells. Journal of Biotechnology, 146, 198-206.

BERTHIER, C. C., LODS, N., JOOSTEN, S. A., VAN KOOTEN, C., LEPPERT, D., LINDBERG, R. L. P., KAPPeler, A., RAUlf, F., Sterchi, E. E., LOtTAZ, D. \& MARTI, H. P. 2006. Differential regulation of metzincins in experimental chronic renal allograft rejection: Potential markers and novel therapeutic targets. Kidney International, 69, 358-368.

BOECKLE, S., VON GERSDORFF, K., VAN DER PIEPEN, S., CULMSEE, C., WAGNER, E. \& OGRIS, M. 2004. Purification of polyethylenimine polyplexes highlights the role of free polycations in gene transfer. Journal of Gene Medicine, 6, 1102-1111.

BORTH, N., MATTANOVICH, D., KUNERT, R. \& KATINGER, H. 2005. Effect of increased expression of protein disulfide isomerase and heavy chain binding protein on antibody secretion in a recombinant $\mathrm{CHO}$ cell line. Biotechnology Progress, 21, 106-111.

BOSSHART, H., HUMPHREY, J., DEIGNAN, E., DAVIDSON, J., DRAZBA, J., YUAN, L., OORSCHOT, V., PETERS, P. J. \& BONIFACINO, J. S. 1994. The cytoplasmic domain mediates localization of furin to the trans-golgi network en-route to the endosomal lysosomal system. Journal of Cell Biology, 126, 1157-1172.

BRAKe, A. J., MeRRYWEATHER, J. P., COIT, D. G., HEBerlein, U. A., MASiARZ, F. R., MULLENBACH, G. T., URDEA, M. S., VALENZUELA, P. \& BARR, P. J. 1984. Alpha-factordirected synthesis and secretion of mature foreign proteins in Saccharomyces-cerevisiae. Proceedings of the National Academy of Sciences of the United States of America-Biological Sciences, 81, 4642-4646.

BREW, K., DINAKARPANDIAN, D. \& NAGASE, H. 2000. Tissue inhibitors of metalloproteinases: evolution, structure and function. Biochimica Et Biophysica Acta-Protein Structure and Molecular Enzymology, 1477, 267-283.

CAin, K., Peters, S., hallu, H., SWEeney, B., Stephens, P., heAdS, J., SARKAR, K., VENTOM, A., PAGE, C. \& DICKSON, A. 2013. A CHO cell line engineered to express XBP1 
and ERO1-L has increased levels of transient protein expression. Biotechnology Progress, 29, 697-706.

CHIA, P. Z. C., GASNEREAU, I., LIEU, Z. Z. \& GLEESON, P. A. 2011. Rab9-dependent retrograde transport and endosomal sorting of the endopeptidase furin. Journal of Cell Science, 124, 2401-2413.

CHUNG, J. Y., LIM, S. W., HONG, Y. J., HWANG, S. O. \& LEE, G. M. 2004. Effect of doxycyclineregulated calnexin and calreticulin expression on specific thrombopoietin productivity of recombinant Chinese hamster ovary cells. Biotechnology and Bioengineering, 85, 539-546.

CODAMO, J., HOU, J. J. C., HUGHES, B. S., GRAY, P. P. \& MUNRO, T. P. 2011. Efficient mAb production in $\mathrm{CHO}$ cells incorporating $\mathrm{PEI}-$ mediated transfection, mild hypothermia and the co-expression of XBP-1. Journal of Chemical Technology and Biotechnology, 86, 923-934.

DARAMOLA, O., STEVENSON, J., DEAN, G., hATTON, D., PETTMAN, G., HOLMES, W. \& FIELD, R. 2014. A High-Yielding CHO Transient System: Coexpression of Genes Encoding EBNA-1 and GS Enhances Transient Protein Expression. Biotechnology Progress, 30, 132-141.

DOOLAN, P., MELVILle, M., GAMMELL, P., SinACORE, M., MELEADY, P., MCCARTHY, K., FRANCULLO, L., LEONARD, M., CHARLEBOIS, T. \& CLYNES, M. 2008. Transcriptional profiling of gene expression changes in a PACE-transfected CHO DUKX cell line secreting high levels of rhBMP-2. Molecular Biotechnology, 39, 187-199.

DORNER, A. J., WASLEY, L. C. \& KAUFMAN, R. J. 1989. Increased synthesis of secreted proteins induces expression of glucose-regulated proteins in butyrate-treated Chinese-hamster ovary cells. Journal of Biological Chemistry, 264, 20602-20607.

DOUGLAS, D. A., SHI, Y. E. \& SANG, Q. X. A. 1997. Computational sequence analysis of the tissue inhibitor of metalloproteinase family. Journal of Protein Chemistry, 16, 237-255.

HAN, J. B., WANG, Y. G., WANG, S. M. \& CHI, C. W. 2008. Interaction of Mint3 with Furin regulates the localization of Furin in the trans-Golgi network. Journal of Cell Science, 121, 2217-2223. 
HAREDY, A. M., NISHIZAWA, A., HONDA, K., OHYA, T., OHTAKE, H. \& OMASA, T. 2013. Improved antibody production in Chinese hamster ovary cells by ATF4 overexpression. Cytotechnology, $65,993-1002$.

HEISS, S., PUXBAUM, V., GRUBER, C., ALTMANN, F., MATTANOVICH, D. \& GASSER, B. 2015. Multistep processing of the secretion leader of the extracellular protein Epx1 in Pichia pastoris and implications for protein localization. Microbiology-Sgm, 161, 1356-1368.

HOU, J., TYO, K. E. J., LIU, Z. H., PETRANOVIC, D. \& NIELSEN, J. 2012. Metabolic engineering of recombinant protein secretion by Saccharomyces cerevisiae. Fems Yeast Research, 12, 491510.

HUSSAIN, H., MALDONADO-AGURTO, R. \& DICKSON, A. J. 2014. The endoplasmic reticulum and unfolded protein response in the control of mammalian recombinant protein production. Biotechnol Lett, 36, 1581-93.

JENKINS, N. \& HOVEY, A. 1993. TEMPERATURE CONTROL OF GROWTH AND PRODUCTIVITY IN MUTANT CHINESE-HAMSTER OVARY CELLS SYNTHESIZING A RECOMBINANT PROTEIN. Biotechnology and Bioengineering, 42, 1029-1036.

JOHARI, Y. B., ESTES, S. D., ALVES, C. S., SINACORE, M. S. \& JAMES, D. C. 2015. Integrated cell and process engineering for improved transient production of a "difficult-to-express" fusion protein by $\mathrm{CHO}$ cells. Biotechnol Bioeng. 112, 2527-2542.

KANTARDJIEFF, A., JACOB, N. M., YEE, J. C., EPSTEIN, E., KOK, Y.-J., PHILP, R., BETENBAUGH, M. \& HU, W.-S. 2010. Transcriptome and proteome analysis of Chinese hamster ovary cells under low temperature and butyrate treatment. Journal of Biotechnology, $145,143-159$.

KAUfMANN, H., MAZUR, X., FUSSENEGgeR, M. \& BAILEY, J. E. 1999. Influence of low temperature on productivity, proteome and protein phosphorylation of $\mathrm{CHO}$ cells. Biotechnology and Bioengineering, 63, 573-582. 
KU, S. C. Y., NG, D. T. W., YAP, M. G. S. \& CHAO, S.-H. 2008. Effects of overexpression of X-box binding protein 1 on recombinant protein production in Chinese hamster ovary and NSO myeloma cells. Biotechnology and Bioengineering, 99, 155-164.

KU, S. C. Y., TOH, P. C., LEE, Y. Y., CHUSAINOW, J., YAP, M. G. S. \& CHAO, S.-H. 2010. Regulation of XBP-1 Signaling During Transient and Stable Recombinant Protein Production in CHO Cells. Biotechnology Progress, 26, 517-526.

LE FOURN, V., GIROD, P. A., BUCETA, M., REGAMEY, A. \& MERMOD, N. 2014. CHO cell engineering to prevent polypeptide aggregation and improve therapeutic protein secretion. Metabolic Engineering, 21, 91-102.

LEE, M. A., CHEONG, K. H., SHIELDS, D., PARK, S. D. \& HONG, S. H. 2002. Intracellular trafficking and metabolic turnover of yeast prepro-alpha-factor-SRIF precursors in $\mathrm{GH}(3)$ cells. Experimental and Molecular Medicine, 34, 285-293.

MALEY, F., TRIMBLE, R. B., TARENTINO, A. L. \& PLUMmER, T. H. 1989. Characterization of glycoproteins and their associated oligosaccharides through the use of endoglycosidases. Analytical Biochemistry, 180, 195-204.

MASON, M., SWEENEY, B., CAIN, K., STEPHENS, P. \& SHARFSTEIN, S. T. 2012. Identifying bottlenecks in transient and stable production of recombinant monoclonal-antibody sequence variants in chinese hamster ovary cells. Biotechnology Progress, 28, 846-855.

MEDZIHRADSZKY, K. F. 2005. Characterization of protein N-glycosylation. Mass Spectrometry: Modified Proteins and Glycoconjugates, 405, 116-138.

MELENDEZ-ZAJGLA, J., DEL POZO, L., CEBALLOS, G. \& MALDONADO, V. 2008. Tissue Inhibitor of Metalloproteinases-4. The road less traveled. Molecular Cancer, 7, 1-11.

MOHAN, C. \& LEE, G. M. 2010. Effect of Inducible Co-Overexpression of Protein Disulfide Isomerase and Endoplasmic Reticulum Oxidoreductase on the Specific Antibody Productivity of Recombinant Chinese Hamster Ovary Cells. Biotechnology and Bioengineering, 107, 337346. 
MOLLOY, S. S., THOMAS, L., VANSLYKE, J. K., STENBERG, P. E. \& THOMAS, G. 1994. Intracellular trafficking and activation of the furin proprotein convertase - localization to the tgn and recycling from the cell-surface. Embo Journal, 13, 18-33.

MOZLEY, O. L., THOMPSON, B. C., FERNANDEZ-MARTELL, A. \& JAMES, D. C. 2014. A Mechanistic Dissection of Polyethylenimine Mediated Transfection of $\mathrm{CHO}$ Cells: to Enhance the Efficiency of Recombinant DNA Utilization. Biotechnology Progress, 30, 1161-1170.

OMASA, T., TAKAMI, T., OHYA, T., KIYAMA, E., HAYASHI, T., NISHII, H., MIKI, H., KOBAYASHI, K., HONDA, K. \& OHTAKE, H. 2008. Overexpression of GADD34 Enhances Production of Recombinant Human Antithrombin III in Chinese Hamster Ovary Cells. Journal of Bioscience and Bioengineering, 106, 568-573.

PENG, R.-W., ABELLAN, E. \& FUSSENEGGER, M. 2011. Differential Effect of Exocytic SNAREs on the Production of Recombinant Proteins in Mammalian Cells. Biotechnology and Bioengineering, 108, 611-620.

PENG, R.-W., GUETG, C., TIGGES, M. \& FUSSENEGGER, M. 2010. The vesicle-trafficking protein munc18b increases the secretory capacity of mammalian cells. Metabolic Engineering, 12, $18-25$.

PENG, R. W. \& FUSSENEGGER, M. 2009. Molecular engineering of exocytic vesicle traffic enhances the productivity of Chinese hamster ovary cells. Biotechnol Bioeng, 102, 1170-81.

PHAM, P. L., PERRET, S., CASS, B., CARPENTIER, E., ST-LAURENT, G., BISSON, L., KAMEN, A. \& DUROCHER, Y. 2005. Transient gene expression in HEK293 cells: Peptone addition posttransfection improves recombinant protein synthesis. Biotechnology and Bioengineering, $90,332-344$.

PYBUS, L. P., DEAN, G., WEST, N. R., SMITH, A., DARAMOLA, O., FIELD, R., WILKINSON, S. J. \& JAMES, D. C. 2014a. Model-Directed Engineering of "Difficult-to-Express" Monoclonal Antibody Production by Chinese Hamster Ovary Cells. Biotechnology and Bioengineering, $111,372-385$. 
'Difficult to Express' Recombinant Proteins

PYBUS, L. P., JAMES, D. C., DEAN, G., SLIDEL, T., HARDMAN, C., SMITH, A., DARAMOLA, O. \& FIELD, R. 2014b. Predicting the Expression of Recombinant Monoclonal Antibodies in Chinese Hamster Ovary Cells Based on Sequence Features of the CDR3 Domain. Biotechnology Progress, 30, 188-197.

RAKESTRAW, J. A., SAZINSKY, S. L., PIATESI, A., ANTIPOV, E. \& WITTRUP, K. D. 2009. Directed Evolution of a Secretory Leader for the Improved Expression of Heterologous Proteins and Full-Length Antibodies in Saccharomyces cerevisiae. Biotechnology and Bioengineering, 103, 1192-1201.

RAYMOND, C., TOM, R., PERRET, S., MOUSSOUAMI, P., L'ABBE, D., ST-LAURENT, G. \& DUROCHER, Y. 2011. A simplified polyethylenimine-mediated transfection process for largescale and. Methods, 55, 44-51.

ROTH, S. D., SCHUTTRUMPF, J., MILANOV, P., ABRISS, D., UNGERER, C., QUADE-LYSSY, P., SIMPSON, J. C., PEPPERKOK, R., SEIFRIED, E. \& TONN, T. 2012. Chemical Chaperones Improve Protein Secretion and Rescue Mutant Factor VIII in Mice with Hemophilia A. Plos One, 7, 1-13.

SCHAFER, W., STROH, A., BERGHOFER, S., SEILER, J., VEY, M., KRUSE, M. L., KERN, H. F., KLENK, H. D. \& GARTEN, W. 1995. 2 independent targeting signals in the cytoplasmic domain determine trans-golgi network localization and endosomal trafficking of the proprotein convertase furin. Embo Journal, 14, 2424-2435.

Seidah, N. G., Benjannet, S., PAREeK, S., SAVARIA, D., HAMElin, J., Goulet, B., LALIBERTE, J., LAZURE, C., CHRETIEN, M. \& MURPHY, R. A. 1996. Cellular processing of the nerve growth factor precursor by the mammalian pro-protein convertases. Biochemical Journal, 314, 951-960.

SELBY, M. J., EDWARDS, R., SHARP, F. \& RUTTER, W. J. 1987. Mouse nerve growth-factor gene structure and expression. Molecular and Cellular Biology, 7, 3057-3064.

SHAPIRO, J., SCIAKY, N., LEE, J., BOSSHART, H., ANGELETTI, R. H. \& BONIFACINO, J. S. 1997. Localization of endogenous furin in cultured cell lines. Journal of Histochemistry \& Cytochemistry, 45, 3-12. 
SIEVERS, F., WILM, A., DINEEN, D., GIBSON, T. J., KARPLUS, K., LI, W. Z., LOPEZ, R., MCWILLIAM, H., REMMERT, M., SODING, J., THOMPSON, J. D. \& HIGGINS, D. G. 2011. Fast, scalable generation of high-quality protein multiple sequence alignments using Clustal Omega. Molecular Systems Biology, 7, 1-6.

STOOPS, J., BYRD, S. \& HASEGAWA, H. 2012. Russell body inducing threshold depends on the variable domain sequences of individual human $\lg G$ clones and the cellular protein homeostasis. Biochim Biophys Acta, 1823, 1643-57.

SUTER, U., HEYMACH, J. V. \& SHOOTER, E. M. 1991. 2 conserved domains in the NGF propeptide are necessary and sufficient for the biosynthesis of correctly processed and biologically-active NGF. Embo Journal, 10, 2395-2400.

TAKAHASHI, S., NAKAGAWA, T., BANNO, T., WATANABE, T., MURAKAMI, K. \& NAKAYAMA, K. 1995. Localization of furin to the trans-golgi network and recycling from the cell-surface involves ser and tyr residues within the cytoplasmic domain. Journal of Biological Chemistry, 270, 28397-28401.

TARENTINO, A. L., TRIMBLE, R. B. \& PLUMMER, T. H. 1989. Enzymatic approaches for studying the structure, synthesis, and processing of glycoproteins. Methods in Cell Biology, 32, 111139.

THOMAS, G. 2002. Furin at the cutting edge: From protein traffic to embryogenesis and disease. Nature Reviews Molecular Cell Biology, 3, 753-766.

TIGGES, M. \& FUSSENEGGER, M. 2006. Xbp1-based engineering of secretory capacity enhances the productivity of Chinese hamster ovary cells. Metabolic Engineering, 8, 264-272.

WALSH, G. 2014. Biopharmaceutical benchmarks 2014. Nature Biotechnology, 32, 992-1000.

XIE, Q., XINYONG, G., XIANJIN, C. \& YAYU, W. 2013. PEI/DNA formation affects transient gene expression in suspension Chinese hamster ovary cells via a one-step transfection process. Cytotechnology, 65, 263-71. 
'Difficult to Express' Recombinant Proteins

ZUCKER, S., DREWS, M., CONNER, C., FODA, H. D., DECLERCK, Y. A., LANGLEY, K. E., BAHOU, W. F., DOCHERTY, A. J. P. \& CAO, J. 1998. Tissue inhibitor of metalloproteinase-2 (TIMP-2) binds to the catalytic domain of the cell surface receptor, membrane type 1 matrix metalloproteinase 1 (MT1-MMP). Journal of Biological Chemistry, 273, 1216-1222. 
'Difficult to Express' Recombinant Proteins

1

2

3

4

5

6

7

8

9

10

11

12

13

14

15

16

17

18

19

20

21

22

23

24

25

26

27

28

29

30

31

32

33

34

35

36

37

38

39

40

41

42

43

44

45

46

47

48

49

50

51

52

53

54

55

56

57

58

59

60

1 Table I Primer details for messenger RNA (mRNA) analysis. Primer sequences for RT-PCR and

2 qRT-PCR are summarised including the GC content, annealing temperature (Ta), and expected

3 product size. Details are shown for the $\beta$-2-microglobulin housekeeping gene (B2M), TIMP-2 and 4 TIMP-3.

\begin{tabular}{|clcccc|}
\hline \multirow{2}{*}{ Target gene } & Primer & Sequence (5'-3') & GC (\%) & Ta $\left({ }^{\circ} \mathbf{C}\right)$ & Product size \\
\hline \multirow{2}{*}{ B2M } & Forward ATATGCCTGCAGAGTTACACACACCACTC & 48.3 & 60 & $182 \mathrm{bp}$ \\
& Reverse & GCCATTACTATTCCTTCCGTGTGCATAGA & 44.8 & & \\
\hline TIMP-2 & Forward & CCATGATCCCCTGCTACATC & 55.0 & & $213 \mathrm{bp}$ \\
TIMP-3 & Forward & CTACTACCTGCCCTGCTTCG & 60.0 & 60 & $215 \mathrm{bp}$ \\
TIMPs & Reverse & CGCAAGCTTATCAGTGGTGA & 50.0 & & - \\
\hline
\end{tabular}




\section{List of Figures}

Figure 1 Amino acid sequence alignment for recombinant TIMP proteins. The amino acid sequences are shown for TIMP-2, TIMP-3 and TIMP-4. Within the sequence the CD33 signal peptide (red), linker (green) and 6×Histidine detection tag (blue) are highlighted. In addition, amino acids fully conserved $\left({ }^{*}\right)$, semi-conserved with strongly similar properties (:) or weakly similar properties (.) are indicated. Multiple sequence alignment was performed using Clustal Omega (Sievers et al., 2011).

Figure 2 Cell growth and viability for transiently transfected CHO cell cultures. CHO-EBNA-GS cultures were transiently transfected with enhanced GFP (control, eGFP), TIMP-2 and TIMP-3 separately. The cell density (total cell count, $\times 10^{6}$ cells $/ \mathrm{ml}$, primary $\mathrm{y}$-axis) and cell viability (\%, secondary $y$-axis) were evaluated over the culture period (x-axis, time, days). Data shown are representative of the mean value \pm SEM for the control $(n=3)$, TIMP-2 and TIMP-3 $(n=4)$.

Figure 3 Messenger RNA analysis of TIMP-transfected $\mathrm{CHO}$ cell cultures. RNA was isolated from TIMP-transfected cultures on days 3, 5 and 6 of culture. The presence of messenger RNA (mRNA) was investigated by reverse transcription polymerase chain reaction (RT-PCR) for TIMP-2 and TIMP3 (a). mRNA was analysed using TIMP-specific primers (top panel) with expected product sizes for TIMP-2 (213bp) and TIMP-3 (215bp). $\beta$-2-microglobulin housekeeping gene (B2M,182bp) was used as a control (bottom panel). The amount of mRNA was compared using quantitative RT-PCR (b). The cycle number at which samples reached the threshold (Ct) was determined. Raw Ct values for TIMPspecific detection were normalised to the control (Ct ratio). The $\mathrm{Ct}$ ratio was used for comparison between different samples. For qRT-PCR, data shown are representative of the mean value \pm SEM $(n=3)$.

Figure 4 Characterisation of secreted and intracellular protein for TIMP-transfected $\mathrm{CHO}$ cell cultures. Cell lysates (intracellular) and culture medium (secreted) samples for transiently transfected CHO-EBNA-GS cultures with TIMP-2 (a) and TIMP-3 (b) were analysed by western blot. Cultures were sampled on day 3, 5 and 6 . Non-transfected cells were used as a control (Ctl) and extracellularsignal-regulated kinase 2 (ERK2) was used as a loading control for intracellular samples. Arrows and associated labels indicate different protein forms detected. Monomers, high molecular weight species 
(high MW) and the non-specific $\mathrm{CHO}$ intracellular protein are labelled. Data shown are representative of at least four biological replicates.

Figure 5 Cellular compartment fractionation analyses of transfected $\mathrm{CHO}$ cell cultures. The intracellular protein localisation of tissue inhibitor of metalloproteinase-2 and -3 (TIMP-2 and -3 ) was analysed using cell fractionation. Transfected cells (day 5 of culture) were processed using the Qproteome $^{\circledR}$ cell compartment kit (QIAGEN). Cells were separated into four fractions, cytosolic (F1), membranes/organelles (F2), nuclear (F3) and cytoskeletal (F4). Samples were analysed by western blot. Images are shown for non-transfected control, TIMP-2 and TIMP-3 (a). Western blots were quantified and the relative proportions of monomers or high molecular weight species (high MW) in each fraction were plotted for TIMP-2 (b) and TIMP-3 (c). Data shown are representative of the mean value $\pm \operatorname{SEM}(n=3)$.

Figure 6 Glycan analysis of intracellular tissue inhibitor of metalloproteinase-3 (TIMP-3) protein and TIMP-3 glycan knockout characterisation. Cell lysates of tissue inhibitor of metalloproteinase-3 (TIMP-3)-transfected cultures (day 5) were treated with Peptide-N-Glycosidase F (PNGase F) and Endoglycosidase $\mathrm{H}$ (Endo $\mathrm{H}$ ) separately. Cleavage sites of each enzyme are indicated on an example glycan structure (a). Untreated (1), denatured (2) and treated (3) samples were analysed by western blot (b). CHO-EBNA-GS cultures were transiently transfected with the TIMP-3 glycan knockout and cell lysates (intracellular) and extracellular medium (secreted) samples isolated and analysed by western blot. Non-transfected cells were used as a negative control (Ctl) and TIMP-3 intracellular sample (day 5) as a comparison. Extracellular-signal-regulated kinase 2 (ERK2) was used as an intracellular loading control. Arrows and associated labels indicate different protein forms detected. Monomers, high molecular weight species (high MW) and the non-specific $\mathrm{CHO}$ intracellular protein are labelled. Data shown are representative of three biological replicates.

Figure 7 Characterisation of TIMP-3 with furin-cleavable pro-sequence (fcTIMP-3) in CHO cell cultures. A schematic is shown of the modified TIMP-3 vector with the signal peptide (SP), furin cleavage sites ( - ), N-glycan sites ( $<$ ) and detection tag (6xHis) highlighted (a). CHO-EBNAGS cultures were transiently transfected with the fcTIMP-3 vector and sampled for intracellular (cell lysate) and secreted (extracellular medium) protein and analysed by western blot (b). Intracellular 
TIMP-2 and TIMP-3 protein samples (day 5) were used as positive controls. Culture medium and cell Iysates of fcTIMP-3 (sampled day 5 post-transfection) were digested with Peptide-N-Glycosidase F (PNGase F) and Endoglycosidase $\mathrm{H}($ Endo $\mathrm{H})$ separately. Untreated (-) and treated (+) samples were analysed by western blot (c). Data is representative of three biological replicates.

Figure 8 Characterisation of TIMP-4 with furin-cleavable pro-sequence (fcTIMP-4) in CHO cell cultures. CHO-EBNA-GS cell cultures were transiently transfected with fcTIMP-4 (a) or cotransfected with fcTIMP-4 and furin (1:1 DNA ratio, b) and analysed for secreted (culture medium) and intracellular (cell lysates) TIMP-3 protein by western blot. Secreted and intracellular samples for non-modified TIMP-4 were used as controls (T4 Ctl, sampled on day 6). Arrows and associated labels indicate different protein species detected. Western blots were quantified using the LI-COR imaging system and the relative amount plotted for the secreted (c) and intracellular monomeric (d-e) protein. Intracellular plots are shown without (d) or with (e) the TIMP-4 intracellular control. The data were analysed by two way ANOVA, where a p value of $<0.05\left(^{*}\right),<0.01\left(^{* *}\right)$ and $<0.001\left(^{* * *}\right)$ was deemed significantly different. Data shown are representative of the mean value $\pm \operatorname{SEM}(n=4)$. 
MPLLLLLPLLWAGALAGSCSCSPVHPQQAFCNADVVIRAKAVSEKEVDSGNDIYGNPIKR TIMP-4 MPLLLLLPLLWAGALAGSCSCAPAHPQQHVCHSALVIRAKISSEKVVPASED-PADTQKM TIMP-3 MPLLLLLPLLWAGALAGSCTCSPSHPQDAFCNSDIVIRAKVVGKKLVKEG------PFGT

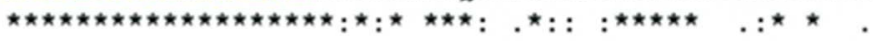

TIMP-2

IQYEIKQIKMFKGPD--KDIEFIYTAPSSAVCGVSLDVGGKKEYLIAGKAEGDGKMHITL TIMP-4 IRYEIKQIKMFKGFEKAKDIQYVYTPFDSSLCGVKLETNSQKQYLLTGQILSDGKVFIHL LVYTIKQMKMYRGFSKMPHVQYIHTEASESLCGLKLEVNK-YQYLLTGRV-YEGKMYTGL

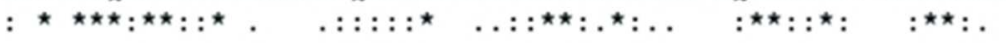

TrMP-2 CDFIVPWDTLSITQKKSLNHRYQMGCECKITRCPMIPCYISSPDECLWMDWVTEKSINGH TIMP-4 CNYIEPWEDLSLVQRESLNHHYHQNCGCQITTCYAVPCTISAPDECLWTDWLLERKLYGY CNFVERWDHLTLSQRKGLNYRYHLGCNCKIKSCYYLPCFVTSKNECLWTDMLSNFGYPGY ${ }^{\star}:::{ }^{\star}:{ }^{\star}::{ }^{\star}:: .^{\star \star}::^{\star}: .^{\star}{ }^{\star}{ }^{\star} .{ }^{\star} \quad:{ }^{\star}:::::^{\star \star \star \star}{ }^{\star}:::{ }^{\star}:$

TIMP-2 QAKFFACIKRSDGSCAWYRGAAPPKQEFLDIEDPHHHHHH QAQHYVCMKHVDGICSWYRGHLHLRKEYVDIVQPHHHHHH TIMP-4 QSKHYACIRQKGGYCSWYRGWAPPDKSISNATDPHHHHHH

Figure 1

$50 \times 38 \mathrm{~mm}(300 \times 300 \mathrm{DPI})$ 


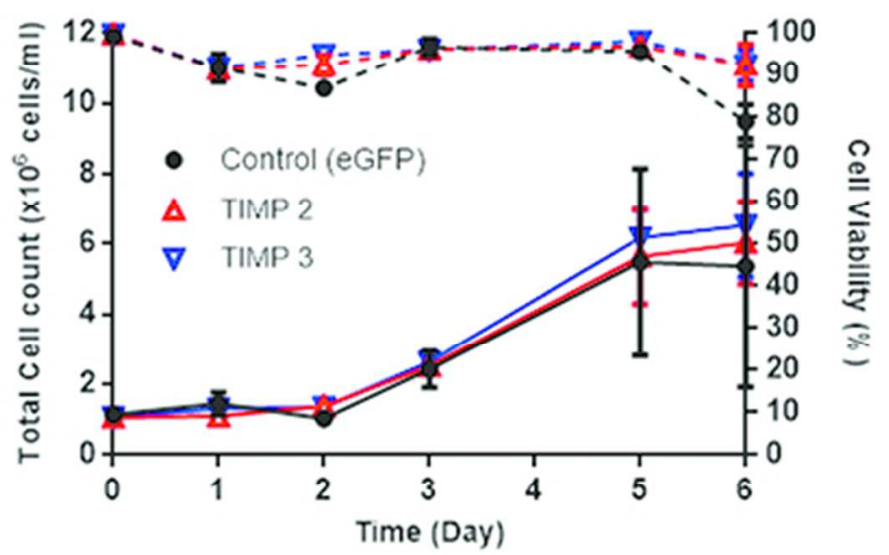

Figure 2

$50 \times 38 \mathrm{~mm}(300 \times 300$ DPI $)$

John Wiley \& Sons 


1
2
3
4
5
6
7
8
9
10
11
12
13
14
15
16
17
18
19
20
21
22
23
24
25
26
27
28
29
30
31
32
33
34
35
36
37
38
39
40
41
42
43
40
45
49
50
51
52
53
55
50

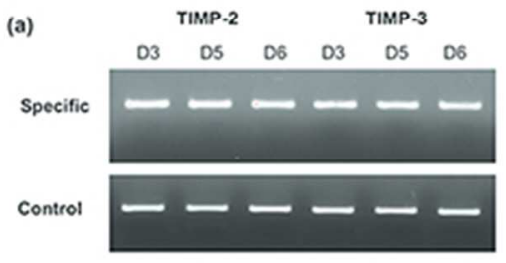

(b)

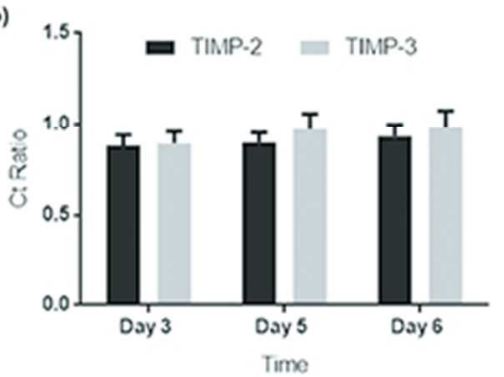

Figure 3

$50 \times 38 \mathrm{~mm}(300 \times 300$ DPI $)$ 
(a)

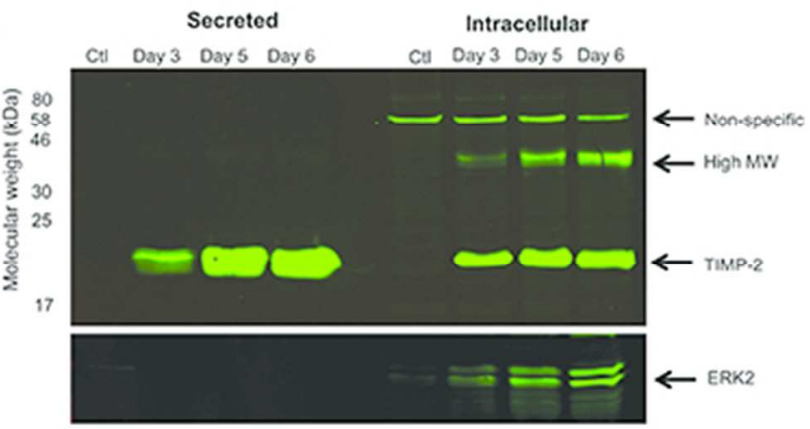

(b)

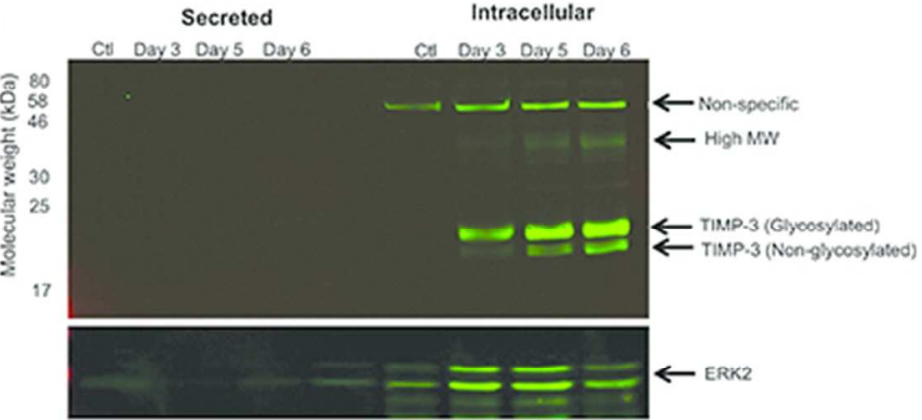

Figure 4

$50 \times 38 \mathrm{~mm}(300 \times 300$ DPI $)$ 

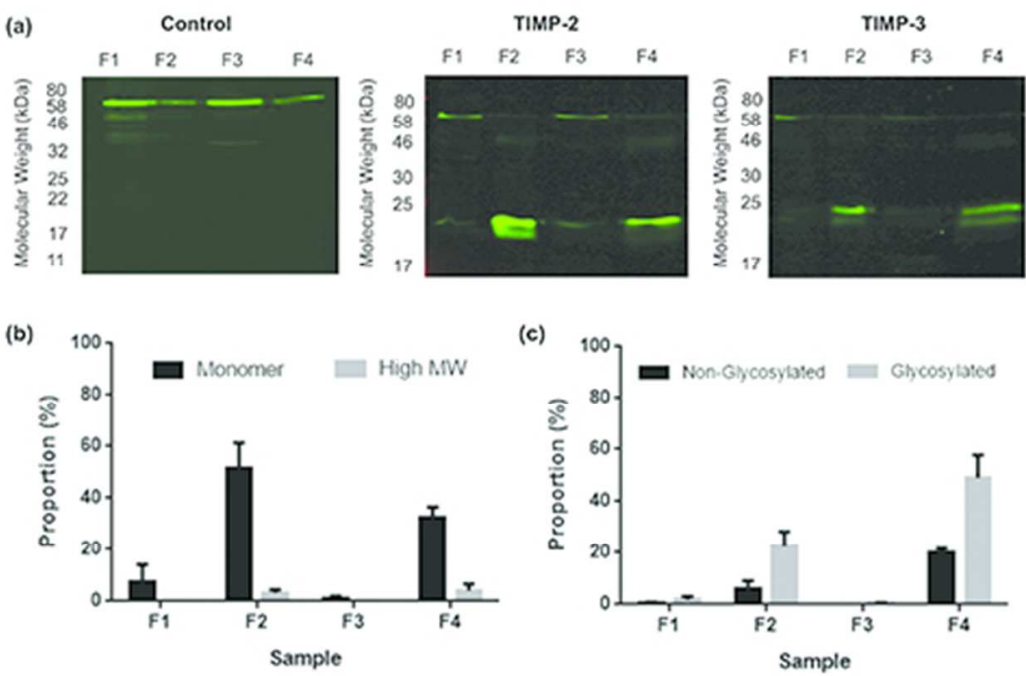

Figure 5

$50 \times 38 \mathrm{~mm}(300 \times 300$ DPI $)$ 
(a)

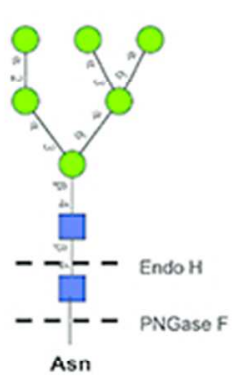

(b)

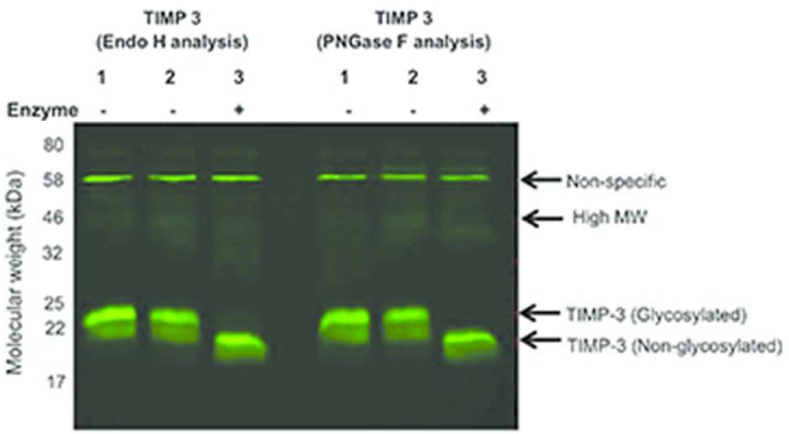

(c)

Secreted

Intracellular

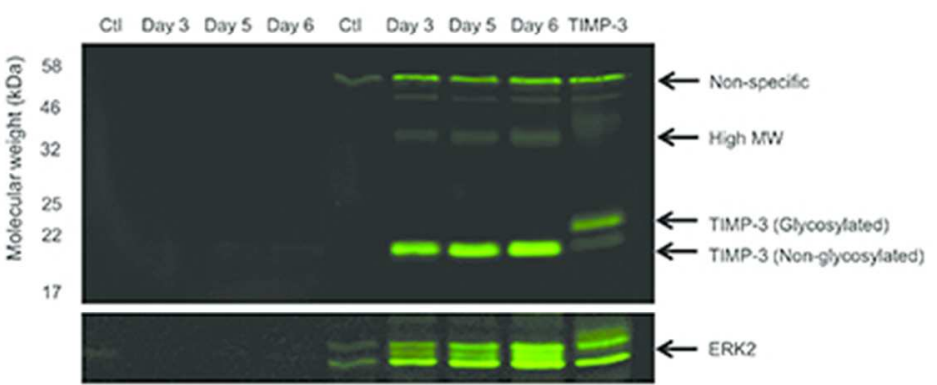

Figure 6

$50 \times 38 \mathrm{~mm}(300 \times 300$ DPI $)$

John Wiley \& Sons 
1

2

3

4

5

6
7

8

9

10

11

12

13

14

15

16

17

18

19

20

21

22

23

24

25

26

27

28

29

30

31

32

33

34

35

36

37

38

39

40

41

42

43

44

45

46

47

48

49

50

51

52

53

54

55

56

57

58

59

60

(a)

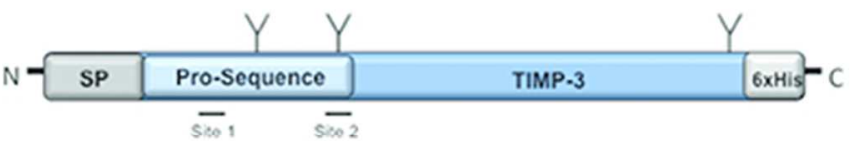

(b)

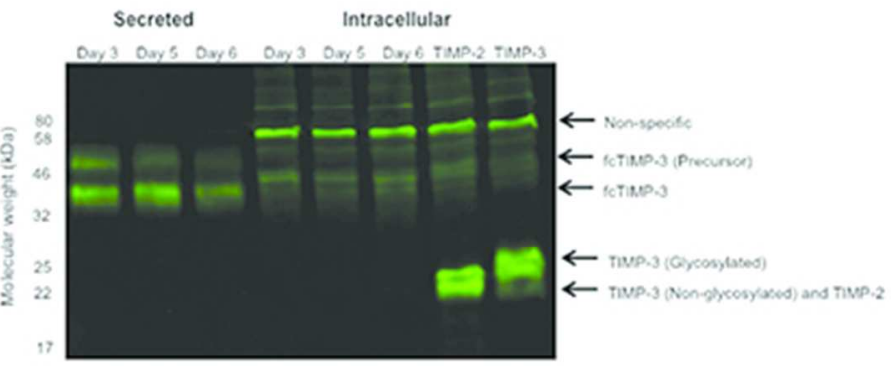

(c)

PNGase $\mathrm{F}$ Endo $\mathrm{H}$ PNGase $\mathrm{F}$ Endo $\mathrm{H}$

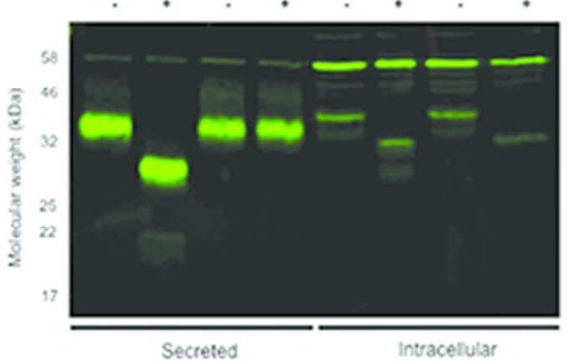

Figure 7

$50 \times 38 \mathrm{~mm}(300 \times 300$ DPI $)$ 

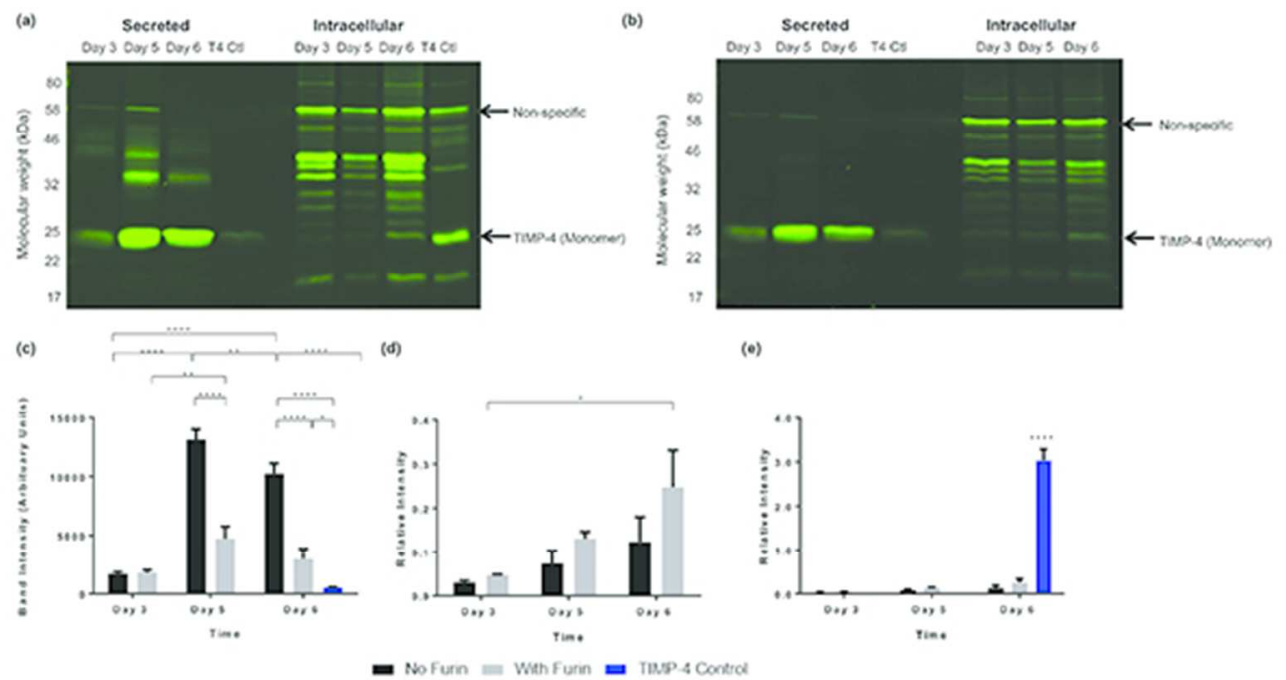

Figure 8

$50 \times 38 \mathrm{~mm}(300 \times 300 \mathrm{DPI})$ 


\section{List of Supplementary Figures}

Figure S1 Initial characterisation of secreted protein of tissue inhibitor of metalloproteinase (TIMP)-transfected $\mathrm{CHO}$ and HEK cell lines. Extracellular medium (secreted) samples for transiently transfected CHO-EBNA-GS (a) and HEK293-6E (b) cultures. Growth and protein expression of TIMP-2 and TIMP-3 in CHO-EBNA-GS cultures was compared at two different temperatures. Extracellular medium samples were harvested at the end of the culture period for $\mathrm{CHO}$ EBNA-GS cells at both $37^{\circ} \mathrm{C}$ (day 7 ) and $30^{\circ} \mathrm{C}$ (day 10) and purified via the $6 \times$ His tag. Similarly, medium samples were harvested from HEK293-6E cultures (day 6) and purified. Both non-purified (crude) and purified samples were analysed via non-reducing SDS-PAGE. Data shown are representative of at least three biological replicates.

Figure S2 Analysis of secreted and intracellular protein under non-reducing conditions for TIMP-transfected CHO cell cultures. Cell lysates (intracellular) and culture medium (secreted) samples for TIMP-2 (a) and TIMP-3 (b) were prepared under non-reducing conditions and analysed by western blot. Cultures were sampled on day 3,5 and 6 . Non-transfected cells were used as a control (Ctl). Arrows and associated labels indicate different protein forms detected. Monomers, high molecular weight species (high MW) and the non-specific $\mathrm{CHO}$ intracellular protein are labelled. Data shown are representative of three biological replicates.

Figure S3 Analysis of the efficiency of cellular compartment fractionation. The intracellular protein localisation of non-transfected cells (control), TIMP-2 and TIMP-3 was analysed using cell fractionation (Qproteome ${ }^{\circledR}$ cell compartment kit, QIAGEN). Different marker proteins were used to test efficiency of separation, ERK2 (cytosolic), BiP (ER), Histone H3 (nuclear) and Flotillin-2 (cytoskeleton). Western blot images for each are shown (a). The blots were quantified and the relative proportion of each marker in the individual fractions were plotted for ERK2 (b), BiP (c), Histone H3 (d) and Flotillin-2 (e). Data shown are representative of the mean value $\pm \operatorname{SEM}(n=6)$.

Figure S4 Analysis of secreted and intracellular protein for TIMP transfected $\mathrm{CHO}$ cell cultures. Culture medium (secreted, top panel) and cell lysates (intracellular, bottom panel) from TIMP-2, TIMP3 and TIMP-4-transfected cultures were prepared under reducing conditions and analysed by western blot (a). Cultures were sampled on day 3,5 and 6 and ERK2 was used as a loading control for 
intracellular samples. Arrows and associated labels indicate different protein forms detected. Monomers, high molecular weight species (high MW) and the non-specific $\mathrm{CHO}$ intracellular protein are labelled. Blots were quantified and the intensity of bands detected was plotted for culture medium samples (b). The band intensity for intracellular TIMP monomers was normalised with ERK2 and the relative intensity plotted against time (c). The data was analysed by two way ANOVA, where a P value of $\left.<0.05\left({ }^{*}\right),<0.01\left(^{* *}\right),<0.001^{(* *}\right)$ and $\left.<0.0001^{(* * *}\right)$ were deemed significantly different. Data shown are representative of the mean value \pm SEM $(n=4)$.

Figure S5 Comparison of the relative amounts of secreted furin-cleavable TIMP-4 (fcTIMP-4) by SDS-PAGE. Samples for secreted protein (culture medium) were taken on days 3,5 and 6 posttransfection from TIMP-2-, TIMP-4- and fcTIMP-4 transfected cultures without furin co-expression. TIMP proteins were purified from culture supernatants (day 6 post-transfection) via the $6 \times$ His tag. Both crude and purified samples were analysed via reducing SDS-PAGE. Gel images are shown for TIMP-2 vs. fcTIMP-4 (a) and TIMP-4 vs. fcTIMP-4 (b). Arrows indicate the expected molecular weight for target proteins. 


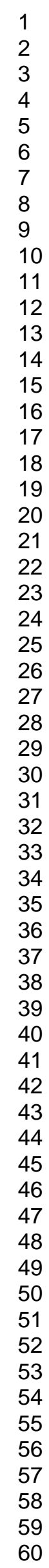

(a)

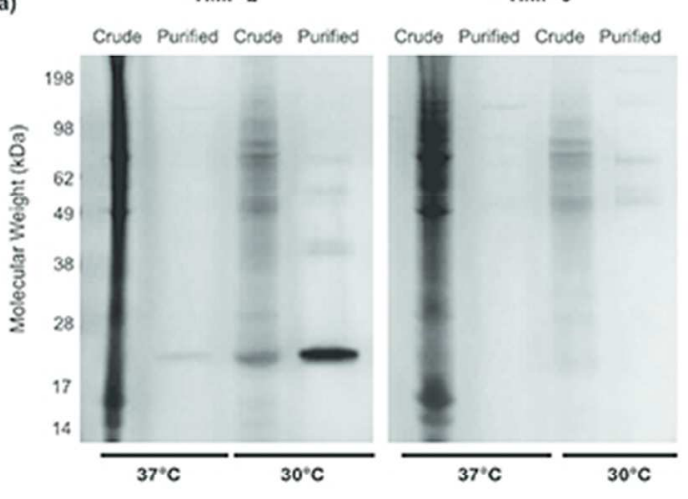

(b) TIMP.2 TIMP-3

Crude Punified Crude Punified 93

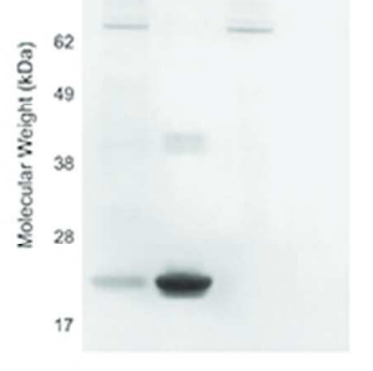

Figure S1

$50 \times 38 \mathrm{~mm}(300 \times 300 \mathrm{DPI})$ 
(a)

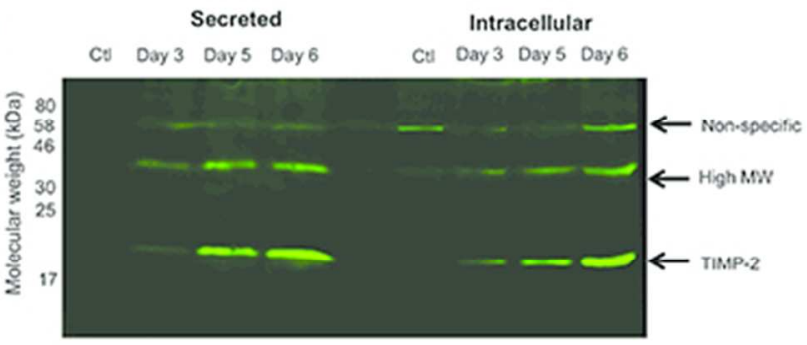

(b)

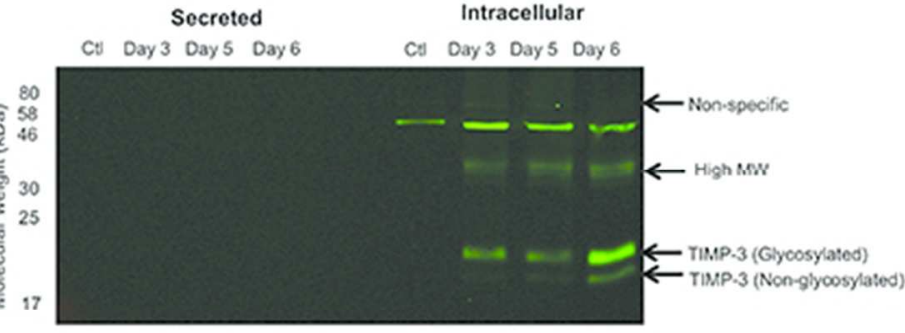

Figure S2

$50 \times 38 \mathrm{~mm}(300 \times 300$ DPI $)$ 
(a)
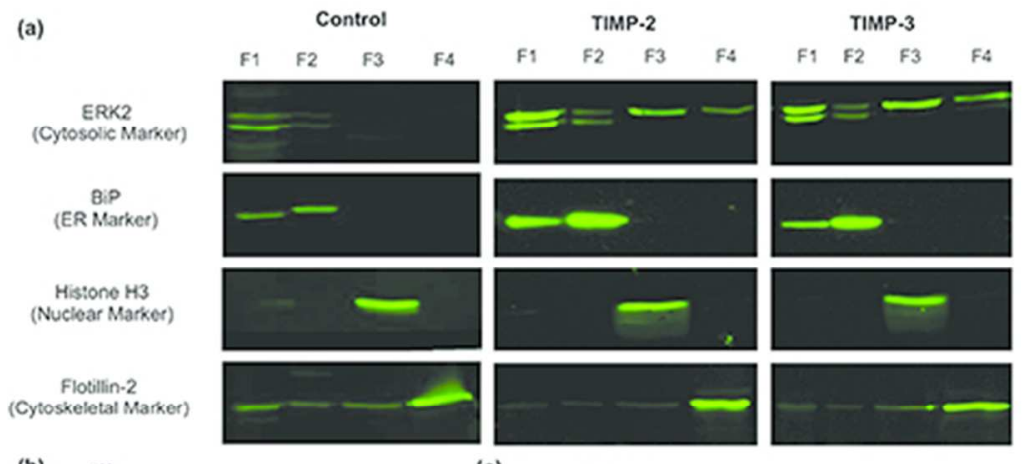

(b)

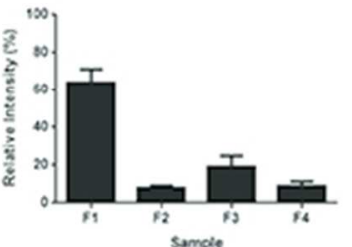

(d)

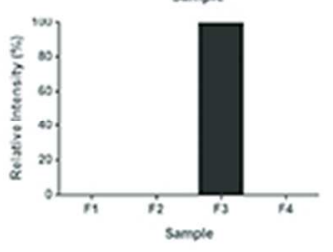

(c)

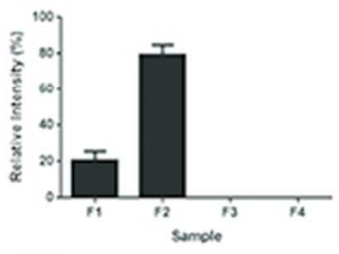

(e)

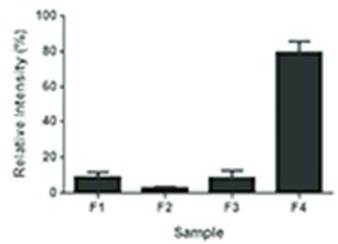

Figure S3

$50 \times 38 \mathrm{~mm}(300 \times 300$ DPI $)$ 
(a)
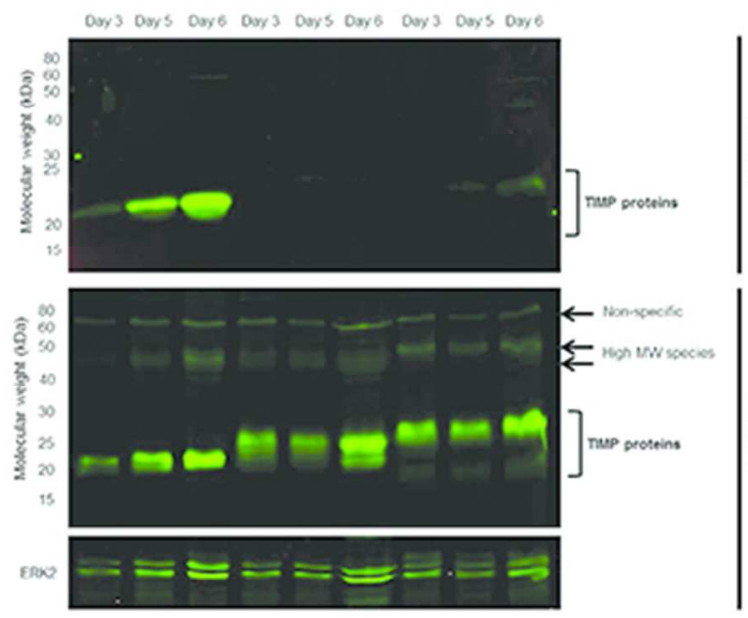

(b)

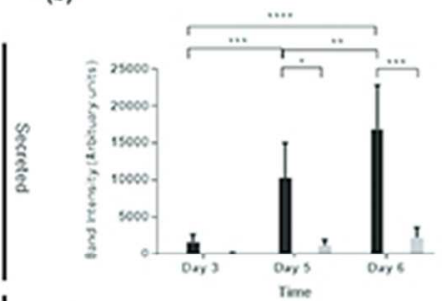

(c)

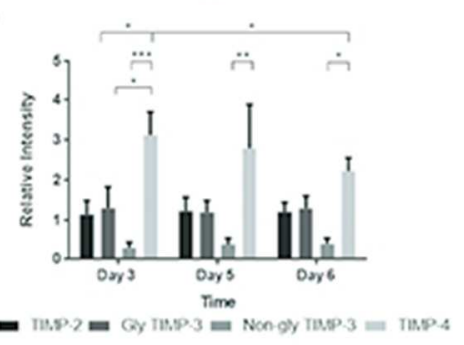

Figure S4

$50 \times 38 \mathrm{~mm}(300 \times 300$ DPI $)$ 

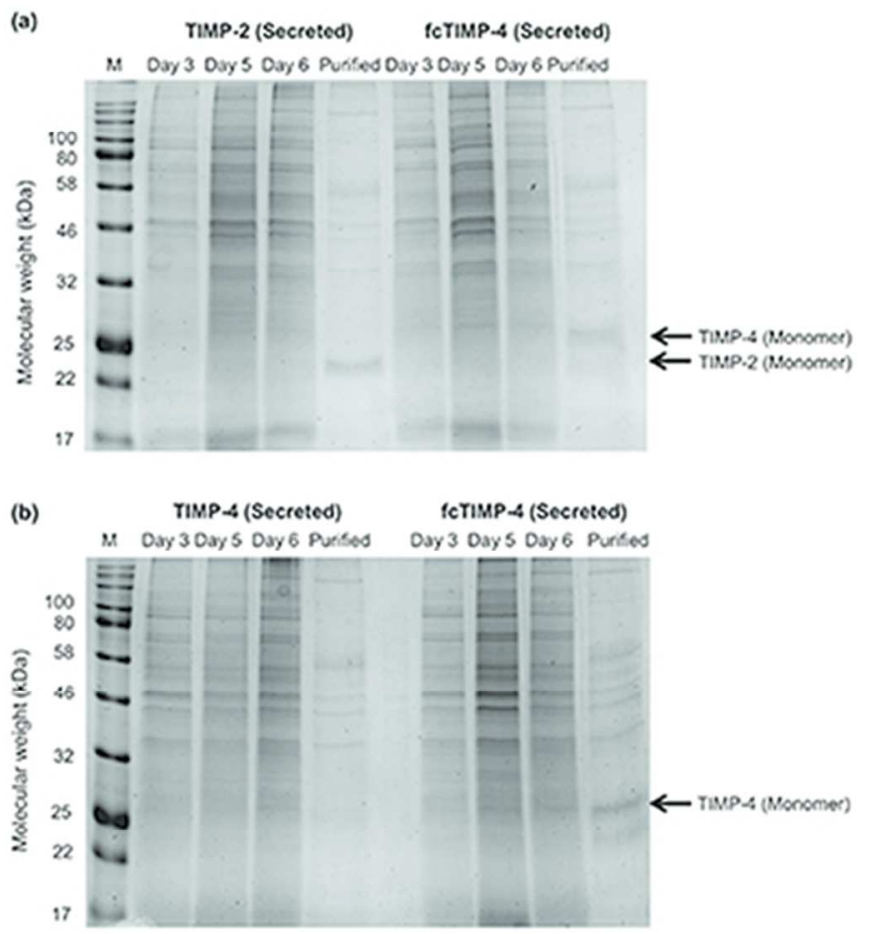

Figure S5

$50 \times 38 \mathrm{~mm}(300 \times 300$ DPI $)$ 